

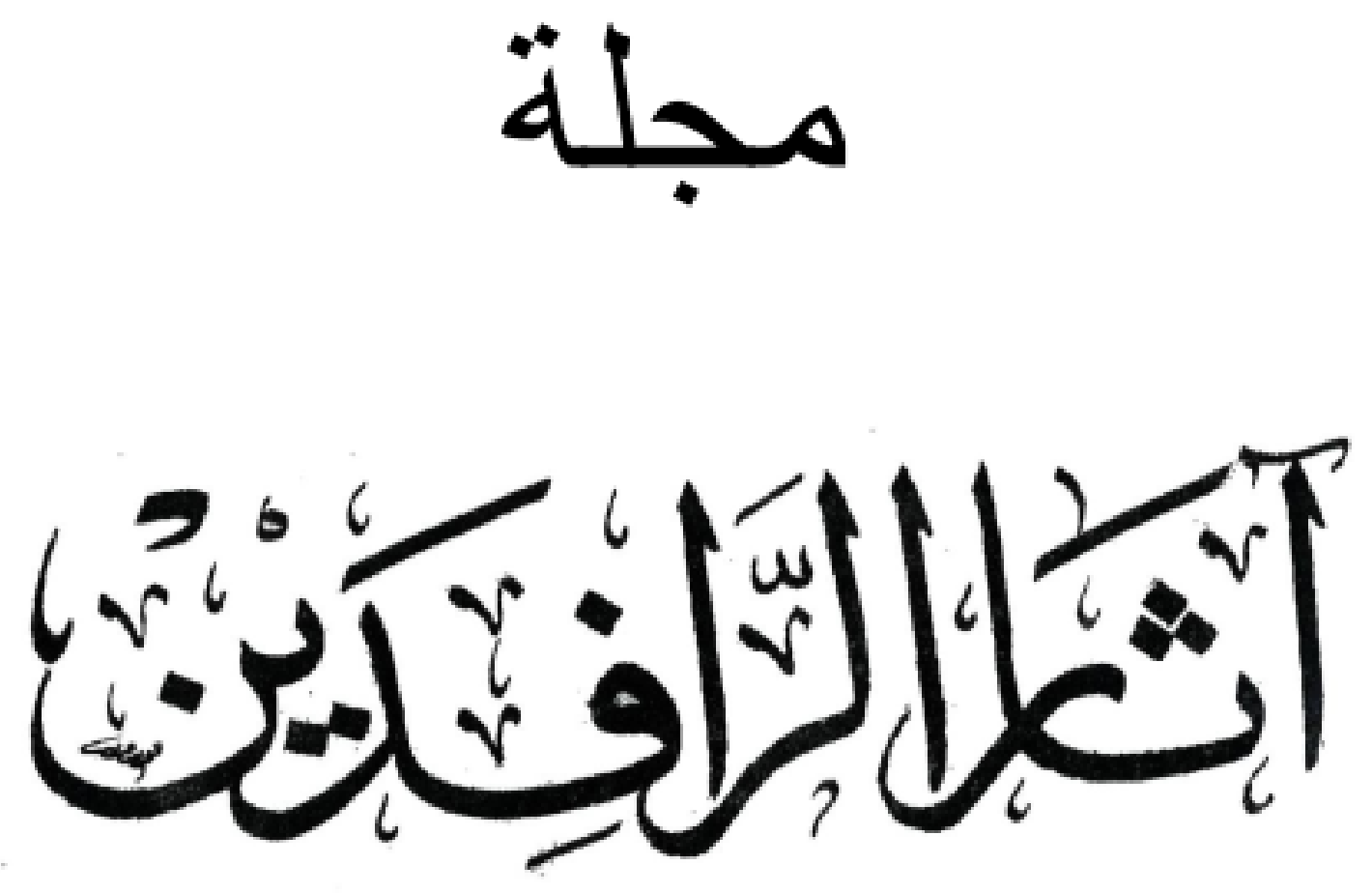

هبلة علمية هحكمة تبحث في آثار العراق و الشرق الأدنى القديم تصدر عن كلية الآثار في جاهعة الموصل

E-Mail: uom.atharalrafedain@ gmail.com البريد الاكتروني

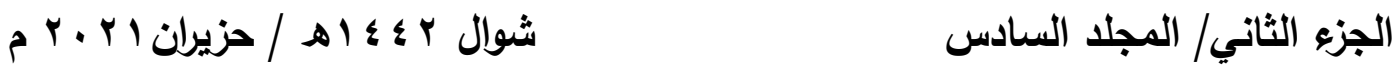

$$
\begin{aligned}
& \text { رقم الايداع في دار الكتب والوثائق بيغداد }
\end{aligned}
$$

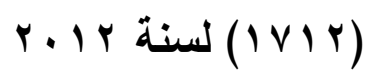





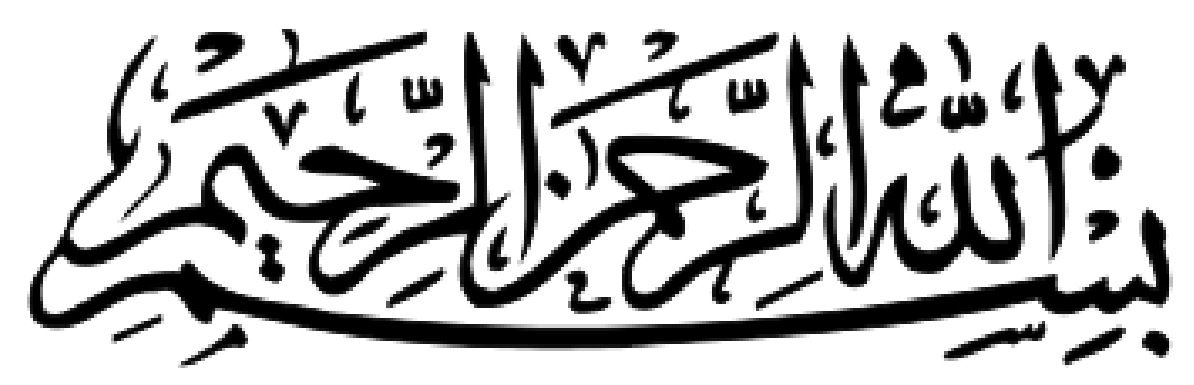





\section{هيأة التمرير}

أ. خالد سالم اسماءيل

رئيس التمرير

أ.م. هسنين حيدر عبد الواحد

الاعضاء

أ.د. اليزابيث ستون

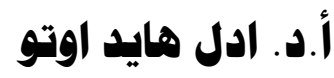

أ.د. والتز سلابيركر

أ.د. نيكولو هاركيتي

أ.د. هديب حياوي عبد الكريم

أ.د. جواد هطر الموسوي

أ.د. رفاه جاسم حمادي

أ.د. عادل هاشم علي

أ.م.د. ياسمين عبد الكريم هممد علي

أ.م.د. فيسان هوفق رشيد

أ.م.د. هاني عبد الغني عبد الله 


$$
\begin{aligned}
& \text { هقوم اللغة العربية } \\
& \text { أ.م.د. همن يميى هصمد }
\end{aligned}
$$

\author{
هقوم اللغة الانكيلية

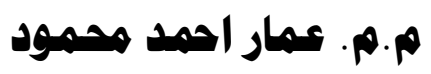 \\ قسم الترجمة / كلية الآداب / جامعة الموصل
}

$$
\text { د. تصميم الغلاف }
$$




\section{قواعد النشر في مجلة آثار الرافدين}

$$
\begin{aligned}
& \text { 1- تقبل المجلة البحوث العلمية التي تقع في تخصصات: } \\
& \text { • علم الاثار بفرعيه القديم والإسلامي . } \\
& \text { • • اللغات القديمة بلهجاتها و الدراسات الدقارنة. } \\
& \text { • الكتابات المسمارية و الخطوط القديمة . }
\end{aligned}
$$

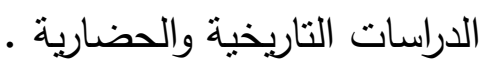

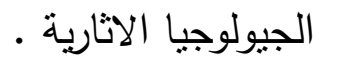

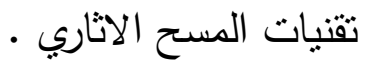

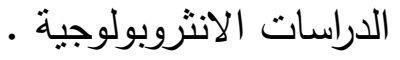

$$
\begin{aligned}
& \text { • الصيانة والتزميم الصنان }
\end{aligned}
$$

r- تقدم البحوث الى المجلة باللغتين العببية أو الانكليزية .

r-يطبع البحث على ورق (A4)، وبنظام (2010 - word)، وبمسافات مزدوجة بين الاسطر ، وبخط Simplified Arabic للغة العربية، و Times New Roman للغة

$$
\text { الانكليزية، ويسلم على قرص ليزري (CD) ، وبنسختين ورقيتين. }
$$

ع- يطبع عنوان البحث في وسط الصفحة يليه اسم الباحث ودرجته العلمية ومكان عمله

$$
\text { كاملاً والبريد الالكتروني (e-mail) }
$$

ه- يجب ان يحتوي البحث ملخصا باللغتين العربية والانكليزية على ان لا تزيد عن (. ( ) كلمة.

4- يحتوي ملخص البحث بالإنكليزية على عنوان البحث واسم الباحث ودرجته العلمية ومكان عمله كاملاً والبريد الالكتروني له. V- تضمين البحث كلمات مفتاحية تتعلق بعنوان البحث ومضمونه. ^- ان لا يكون البحث قد تم نشره سابقا أو كان مقدما لنيل درجة علمية أو مستلاً من ملكية

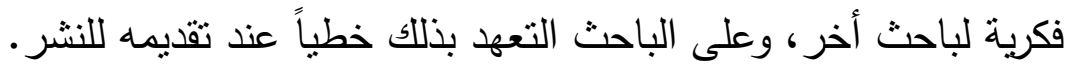
9- يلتزم الباحث باتباع الاسس العلمية السليمة في بحثه. • 1- يلزم الباحث بتعديل فقرات بحثه ليتناسب مع مقترحات الخبراء واسلوب النشر في 
11- لا تتجاوز عدد صفحات البحث عن (ro)، صفحة وفي حال تجاوز العدد المطلوب يتكفل الباحث بدفع مبلغاً اضافياً عن كل صفحة اضافية.

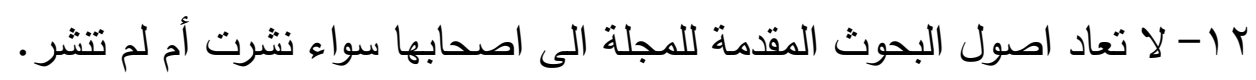
با ا-ترقم الجداول والاشكال على التوالي وبحسب ورودها في البحث، وتزود بعناوين، وتقدم بأوراق منفصلة وتقام المخططات بالحبر الاسود والصور تكون عالية الدقة. ع ا-تكتب ارقام الهوامش بين قوسين وترد متسلسلة في نهاية البحث.

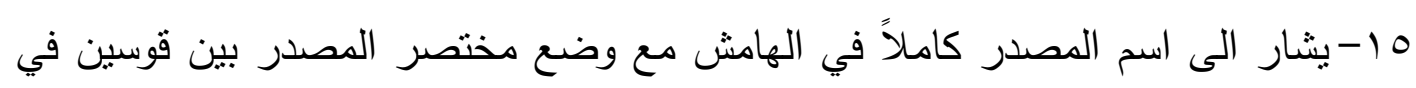
نهاية الهامش.

17 - يتحمل الباحث تصحيح ما يرد في بحثه من اخطاء لغوية وطباعية. V V Vعمل المجلة وفق التمويل الذاتي، ولذلك يتحمل الباحث اجور النشر البالغة

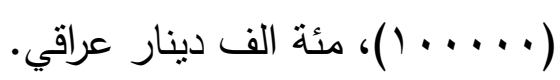

11 ا- يزود كل باحث بمستل من بحثه، أما نسخة المجلة كاملة فتطلب من سكرتارية المجلة

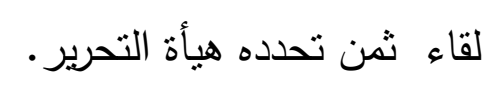
9 1 - ترسل البحوث على البريد الالكتروني للمجلة: uom.atharalrafedain@gmail.com 
ثبت المحتويات

\begin{tabular}{|c|c|c|}
\hline العنوان & اسم الباحث & الصفحة \\
\hline توطئة & أ. خالد سالم اسماعيل & 1 \\
\hline النخيل في الفن العراقي القديم & أ.د. واثق اسماعيل الصالحي & $\Delta r-r$ \\
\hline أضواء على المراسيم الملكية من العصر البابلي القديم & أ. خالد سالم اسماعيل عبد الغني & $q \leq-\Lambda r$ \\
\hline من مدن القوافل ومحطات الطرق على مر العصور التأريخية القديمة & أ.د. عامر عبد الله الجميلي & $1 r r-90$ \\
\hline شجرة الطرفاء في ضوء الكتابات المسمارية & 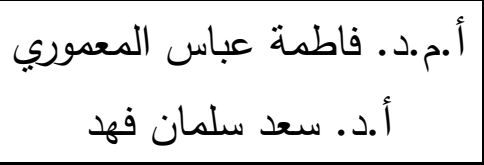 & תrו-. \\
\hline 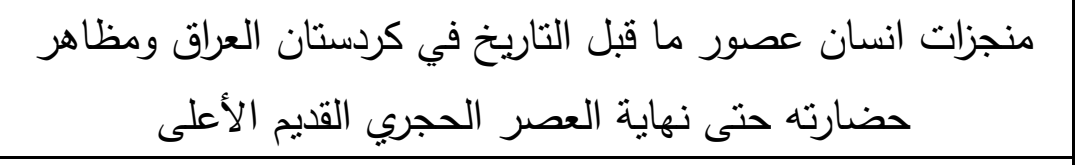 & أ.م.د. نعمان جمعة ابراهيم & $|\wedge 7-17|$ \\
\hline 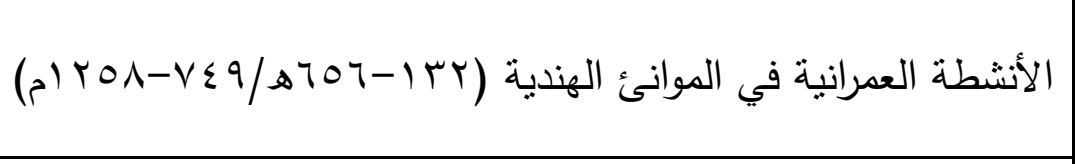 & أ.د. م. قاسفم عمر علاوي ياسين ابراهيم & $r \cdot \varepsilon-1 \wedge V$ \\
\hline ل المظاهر النظافة في المجتمع الحثي & أ.م.د. هاني عبدالغني عبداله & YrI-Y.0 \\
\hline الصيغة المزيدة بالتاء (Gt) في اللغة الأكدية دراسة صرفية دلالية & د. مصطفى محسن محمد & YO.-YYT \\
\hline 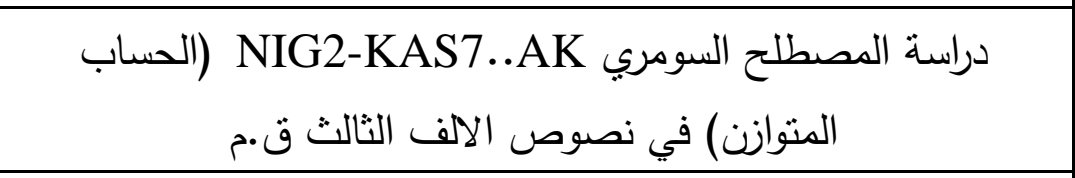 & م.م. عبد الدُكرِمِ محمود العزّي & rтq-rol \\
\hline تطور صناعة المنجل في العراق القديم خلال العصر الحجري الوسيط & م•م• حسن مهدي حمودي & $Y \wedge V-Y V I$ \\
\hline
\end{tabular}



منجزات انسان عصور ما قبل التاريخ في كردستان العرلق ومظاهر حضارته

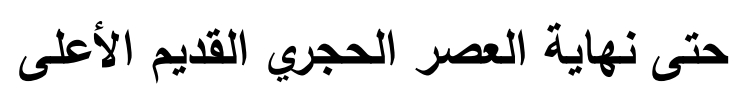

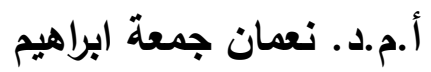
جامعة صلاح الدين / كلية الآداب -قدم الآثار

noman.ibrahim@su.edu.krd

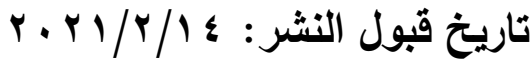

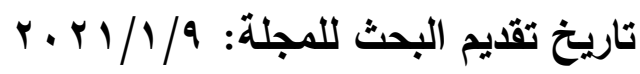

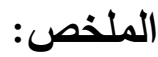

تميزت أرض كردستان بالتبـاين في التضـاريس والبيئة والمنـاخ .وكانت للخصـائص

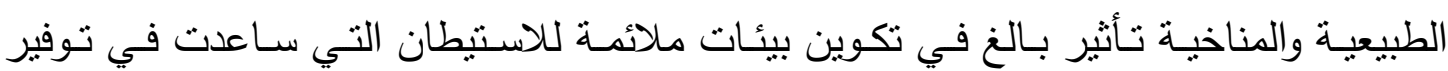

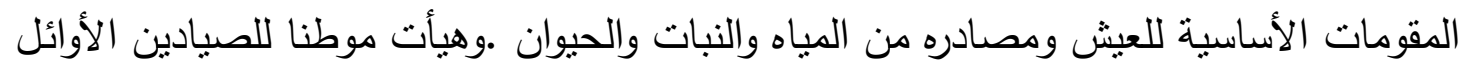

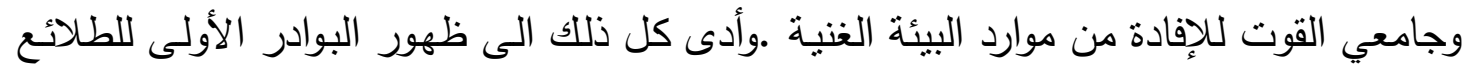

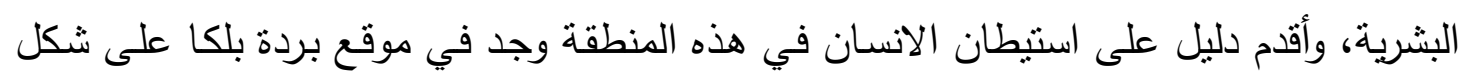

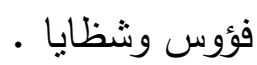
أناحت التنقيات الأثرية التي أجريت في مواقع عديدة من كردستان معلومات مهمة في

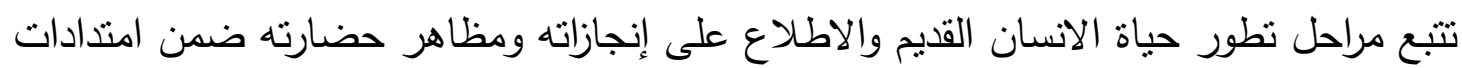

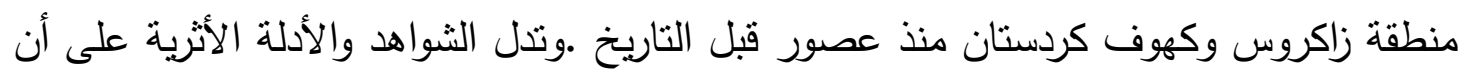

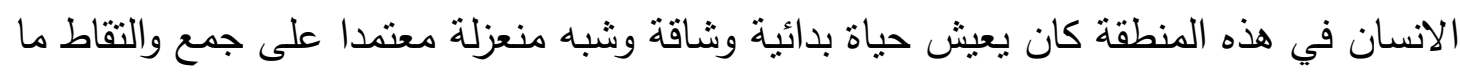

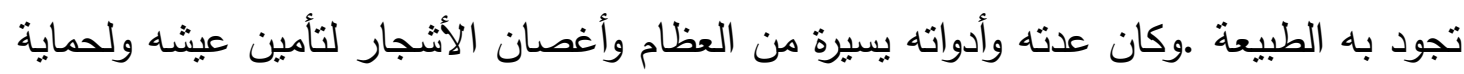
نفسه من الأخطار والتهديدات قبل توصله معرفة صناعة أدواته من الحجارة.

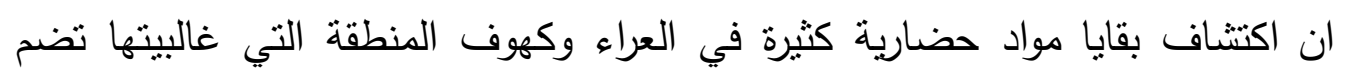

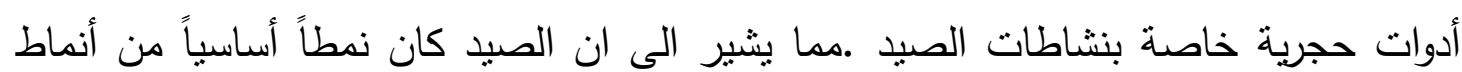

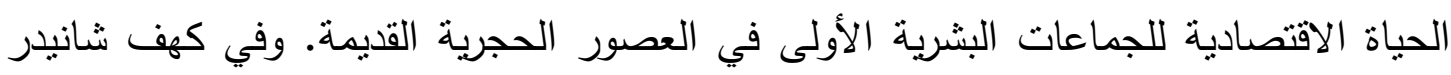
أحدى الكهوف المعروفة ضمن امتدادات الثمالية الغربية من جبال زاكروس استوطنه الانسان في العصر الحجري القديم بسبب ملاعمة الحالة المناخية لموقع الكهف وغنى المنطقة بمصادر لئه

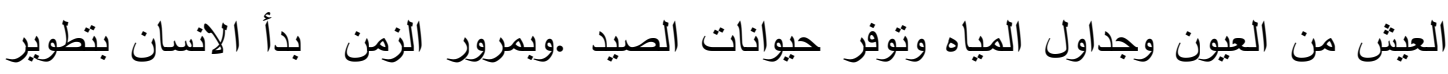
الآلات الحجرية تدريجيا وتتوعت أنتكالها ووظائفها عبر مراحل حضارية طويلة ،وكان تطورها

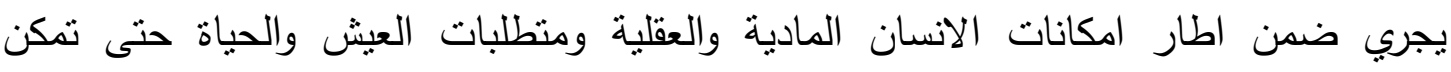
بواسطتها التغلب على البيئة الطبيعية وأصبح سيدا عليها، لذا يرى الباحثون ان نوصل التهل الانسان 


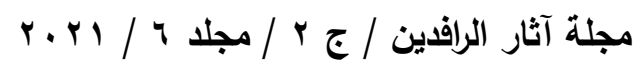

$$
\begin{aligned}
& \text { لصنع الأدوات الحجرية تمنل خطوة مهمة وانجازا كبيرا نحو تطور والارتقاء الحضاري للجماعة } \\
& \text { البشرية. } \\
& \text { وتتاول البحث بإسهاب أبرز منجزات الانسان القديم الدور المتميز لهذه المنطقة في } \\
& \text { سجل الحضارة الانسانية .وأثزها في تغيير نمط الحياة ودورها في ظهور الاستيطان وفي إعطاء } \\
& \text { صورة واضحة عن } \\
& \text { الكلمات المفتاحية: عصور ما قبل التاربخ ، الحضارة ، العصر الحجري القديم الأعلى }
\end{aligned}
$$

\title{
The Achievements of Prehistoric Human in Iraqi Kurdistan and Manifestations of his Civilization Until the End of the Upper Paleolithic
} Assist-Prof.Dr.Noman Jumaah Ibrahim Salahaddin University/ Faculty of Arts Department of Archaeology

\begin{abstract}
:
The land of Kurdistan was distinguished by variations in terrain, environment and climate. The natural and climatic characteristics had a great influence in creating environments suitable for settlement. This helped to provide the basic necessities for living and its sources of water, plants and animals. It provided a home for early hunters and collectors of food to benefit from the rich environment resources. This led to the emergence of the first signs of the human pioneers, and the oldest evidence of human settlement in this area was found at the Burdat Balka site in the form of axes and shrapnel.

The discovery of remnants of many civilized materials in the open and caves of the region, most of which contain stone tools for hunting activities. Indicates that hunting was a basic pattern of economic life for the first human groups during the ancient stone ages. The Shanidar Cave is one of the ancient caves within the northwestern extension of the Zagros Mountains, which was settled by humans during the Paleolithic period due to the suitability of the climatic condition of the cave site and the richness of the region with livelihoods and with springs and streams and the availability of hunting animals.

This will deal with extensive research in order to contribute to giving a clear picture of the distinguished role of this region in the record of human civilization.
\end{abstract}

Keywords: Prehistoric Ages, Civilization, Upper Palaeolithic. 
شغلت عصور ما قبل التاريخ القسم الأعظم من حياة الانسان التي استمرت فترة طويلة

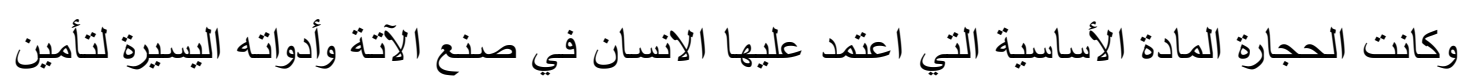

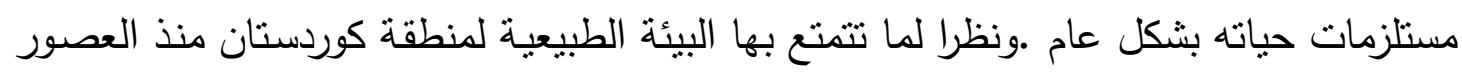

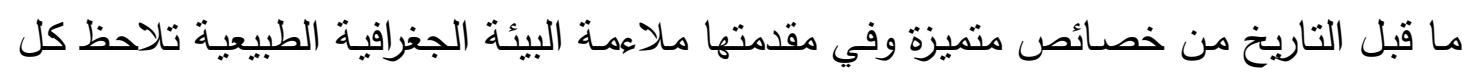

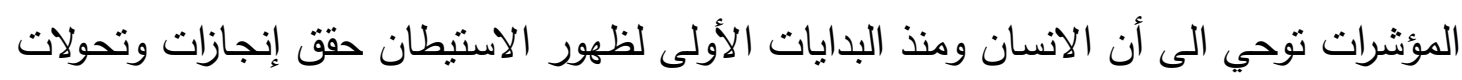

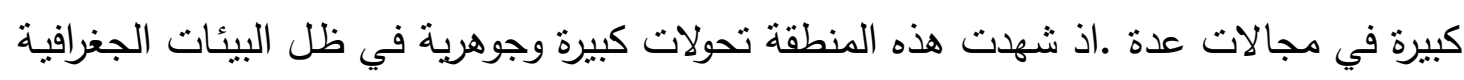

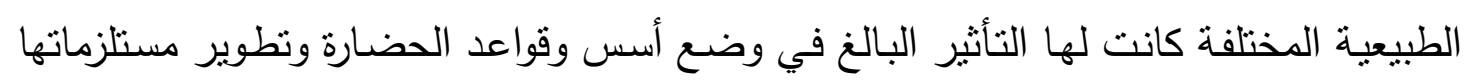
مع تصاعد التفاعل المستمر بين الانسان والبيئة عبر الأزمنة الطويلة.

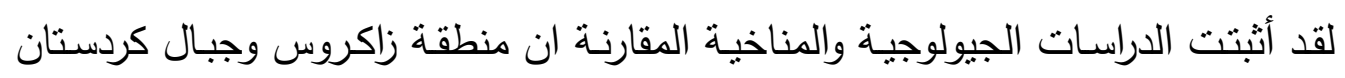

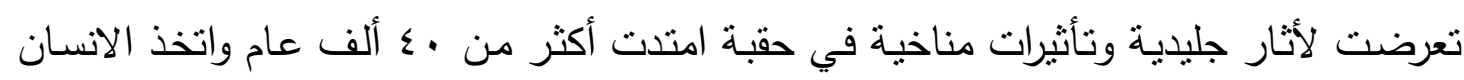

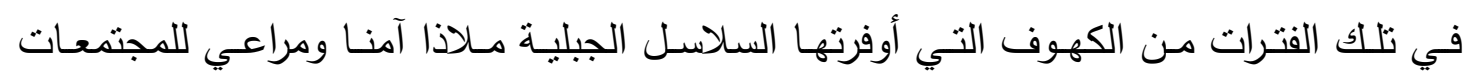
الرعوية.

اقتضت مادة البحث ان نستعرض موضوع انجازات الانسان القديم في كردستان ومظاهر

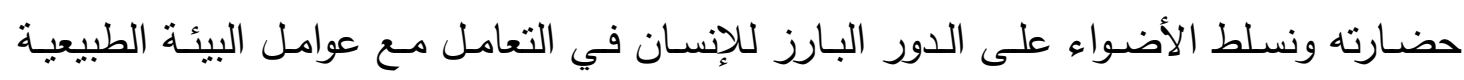

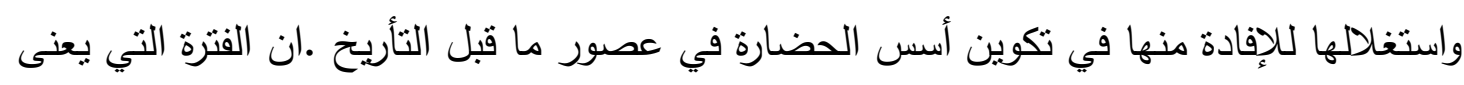

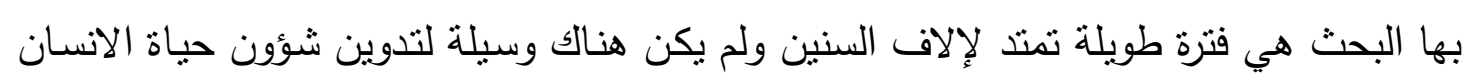

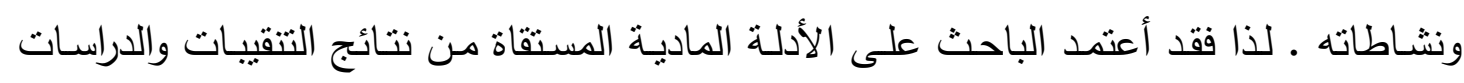

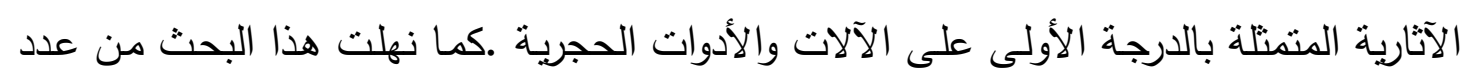

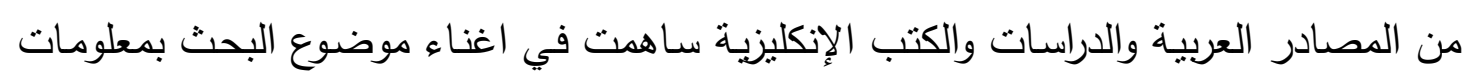
مفيدة . من المعاد

\section{هدف البحث:}

هو معرفة الجذور الأولى لإنجازات الانسان القديم في كردستان واعطاء صورة واضحة

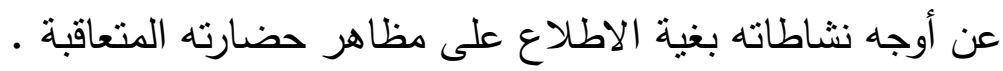
حدود البحث: الحدود المكانية كردستان العراق

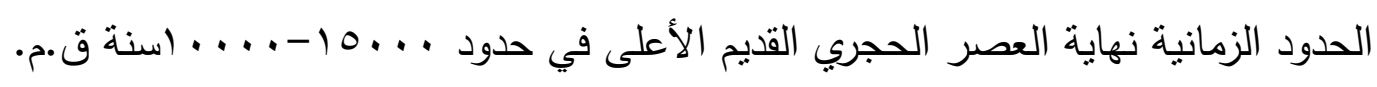




\section{الخلفبة الجغرافية لمنطقة كردستان :}

يطلق مصطلح كردستان (')على منطقة لها سمات جغرافية محددة وتضاربسية منباينة تضم سلاسل جبلية شاهقة ووعرة ومرتفعات شبه الجبلية والسهول والوديان والهضـاب والتنال ،

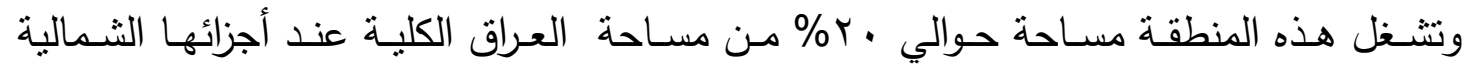
والثـمالية الثـرقية مـن العراق حاليا). تؤلف هذه المنطقة وحدة جغرافيـة تضم النطـاق الجبلي المعقد التي تمتد من الجهات الثمالية والثمالية الثرقية ،أصبحت مسرحا للنشاطات الانسانية

منذ أقدم العصور • وتشكل الحدود السياسية الحديثة المشتركة لكل من ايران وتركيا والعراق (؟).

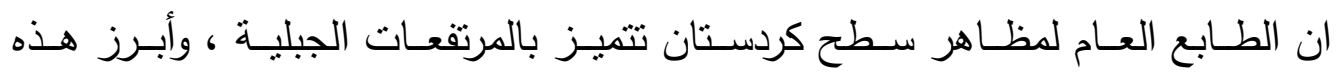
المرتفعات تبدأ بسلاسل جبال زاكروس البالغ طولها . . 7 اكم تقريبا وعرضـها يتراوح ما بين . . . . . . זكم وهي تخترق عددا من السهول والوديان الممتدة من الجهات الثمالية والثمالية الثرقية ، منثل سهل شهرزور وسهل بنجوين وسهل بشدر وسهول حرير وديانا وسهل أربيل بين الزابين الأعلى والأسفل حتى تصل الى السفوح الغربية لجبال زاكروس في ايران لتشمل سهول

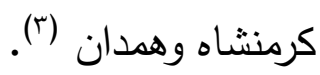
أما بحسب الدراسات الجيولوجية فان الأجزاء الثمالية من الكرة الأرضية تعرضت لأربع فنرات جليدية منذ أزمان مثباعدة تخللتها فترات دافئة .فقد تمكن العالم الألماني (بينك-Penck) من تشخيص أربعة عصور جليدية، سميت بأسماء مناطق الثلاجات في جبال الألب والأنهار في أوروبا التي وجدت فيها أثار نراكمات كتل الجليد في تلاك العصور وتخللتها فنرات دافئة (؛). في حين كانت الأجزاء الجنوبية من الكرة الأرضية وبضمنها منطقة الشرق الأدنى القديم وأجزاء من كردستان وبعض منـاطق الصـحاري منها الصـحراء العربيـة الكبرى والأفريقيـة قد شـهدت فترات دفء وعصور ممطرة مما تركت أثرا كبيرا على حياة الانسان والحيوان والنبات على السواء. مما وفرت فرص العيش للصيادين في تلك المناطق • ومن أهم الفترات الجليدية هي (كنز Gunz)

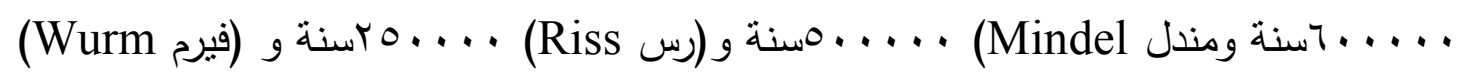

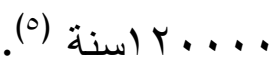

لقد حدث في الفترات الجليديـة تجميد المياه والمحيطات وتراكم الجليد ،ممـا أدى الى لى تراجع حجم المحيطات ـأمـا عند ذوبـان الجليد فقد حصل تبدل في مستوى البحر انحسـارا أو امتذادا .دلت على ذلك خطوط الثُواطئ القديمة ممثلة بجروف صخرية وترسبات بحرية .وهكذا تم تحديد مد بحري ( Transgressions)في مناطق عديدة ،منها منطقة البحر المتوسط .حيث جرت محاولـة ربـط المسـتوبات البحريـة العاليـة في تلك المنطقة وتعاصـرها في منطقـة جبـال

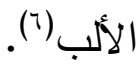


منجزات انسان عصور ما قبل التاريخ في كردستان العراق ومظاهر حضارته حتى نهاية العصر الحجري القديم الأعلى مئى

أمسا عن الوضع الجيولوجي والتكوين الطبيعي لأرض كردستان ، فقد أظهرت التحريات الجيولوجية أن أرض كردستان تكونت مع الأقسام الأخرى للعراق على أثر الحركة الألبية التي ضغطت الرواسب البحرية المتجمعة في قاع بحر تش Tethys الذي كان يغمر معظم مساحة العـراق والمنـاطق المجـاورة لهـا (v). وكـان هـذا البحر في العصـر البرمسي في أواخـر الـدهر الجيولوجي الأول يغطي منـاطق شاسعة يمتد عبر سـوريا ولبنـان والعـراق وايـران وحتى شـمال الهند (^)

وفي أوائل فترة البلايستوسين(دهر الحيـاة الحديثة ) تكاملت جبـال كردستان وأخذت سلاسل جبال زاكروس شكلها الحالي ،بحيث أصبحت سلاسل جبال كردستان نشكل الجزء المهم

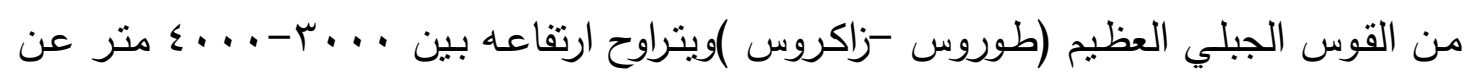
مسـتوى سطح البحر .يفصـل هذا الامتداد الشاسـع الأراضـي السـهلية الواقعـة بـين الهضـبنتين الإيرانيـة والأناضولية وجنوب غرب آسيا جيولوجيا ومناخيا وحضـاريا .وتكثر في هذه الجبال الكهوف والمغارات التي آوى اليها الانسان في العصور الحجرية القديمة ـ يقدر زمن تكوينها الى نهاية عصر البلايستوسين بنحو مليون الى نصف مليون سنة أوفرت هذه السلاسل الجبلية مـاذا آدنا للإنسان ومراعي للمجتمعات الرعوية (9). أما بالنسبة لآثار الثناجات البلايستوسينية في كردستان ،فقد ظهرت آثارها في عدد من المواقع الأثرية في كردستان ،منها سهلي في جمجمال وسلاسل الجبال في منطقة رواندوز وهـه لكورد وكلالة ووادي الزاب الأعلى حتى طرووس .وتبين أن تللك المناطق بما فيها سلاسل جبال زاكروس قد تكونت بسبب الحركات الأرضية والتغيرات المناخية التي حدثت في العصر الجليدي البلايستوسيني وتكاملت في أحدى الحقب الجيولوجية الأربعة وهو العصر البلايستوسين الذي بدأ قبل حوالي . . ألف - . بألف سنة. كما أثنارت تلك الدراسة الى حصول تطورات هامة في هذا العصر منها استقرار المعالم التضاريسية للأرض و ظهور الانسان (·'). حددت الدراسـات المقارنـة لترسبات التربـة وغبار الطلّع في البحيرات وسـاحل الأنهار والكهوف في منطقة زاكروس وجبال كردستان أثنار جليديـة وتأثثرات لأحوال المنـاخ في حقبـة

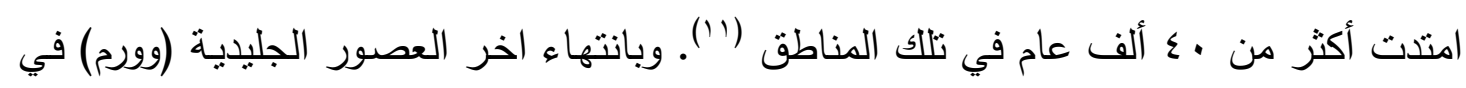
حدود - r ألف سنة بدأ المناخ بـالتغير ،على أثرهـا أصبحت تلك المناطق ملائمسة في حالتها المناخية مع سقوط أمطارا غزيرة ،مما وفرت ظروف بيئية أيكولوجية مثالية لأنواع من الحيوانات البرية ولنمو أصناف من النباتات انعكست ذلك في رسم خارطة توزيع وانتشار تجمعات بشرية من الصيادين التي وفرت لهم امكانات فرص الصبد فيها (rا'). 
فقي كهف شـانيدر (شكل ( )حددت ثغرتان تقعان ضـن أعلى مـا وصـل اليهـ الزحف الجليدي ورافقها انخفاض لدرجة الحرارة وهذه التغيرات المناخية قد أثرت على النباتات والحيوانات ودفعت انسان العصر الحجري القديم أتخاذ الكهوف والماجهئ مـأوى في هذا العصر .وبسبب

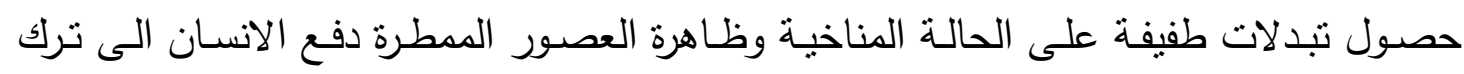
الكهوف تدريجيا واللجوء الى المستوطنات المكثوفة في الفترات اللاحقة (r'). ازدهرت في هذا المتلث حضارات عديدة أنجزها الانسان عبر السنين أسهوت في بنائها أقوام وشـوب مختلفة في شتى المراحل الحضـارية لم تدانها في الأهميـة والنوعية أيسة حضـارة أخرى ،عرفت بحضارة بلاد الرافدين (ء ا'). وبسبب الخصائص الجغرافية لكوردستان المتميزة بجبالها وسـهولها ووديانها الغنية بثروات طبيعية ، أصبحت مأهولة بالسكان منذ العصور القديمة وفرت فيها مستلزمات و أسس الحضارة

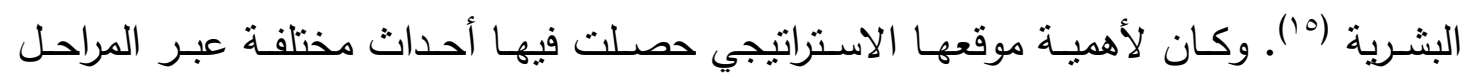
التاريخية منها السياسية ،وفي أعقابها قسمت أراضيها في اطار الدول كل من (العراق وسوريا وايران وتركيا) (17)

الظروف الاقتصادبية ونمط معيشة أنسان كردستان في عصور قبل التأريخ: (Iv) توسـت في الآونـة الأخيـرة دراسـات وبحسوث في الميـادين العلميـة ،منهـا علم الآثار

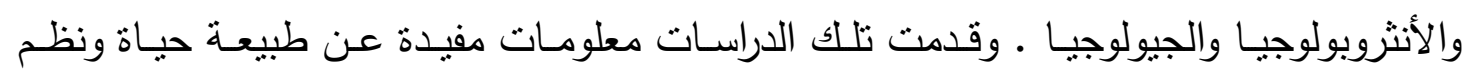

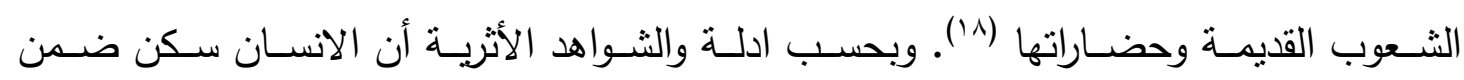
امتدادات منطقة زاكروس وكهوف كردستان منذ عصور ما قبل التاريخ وعاش حياة بدائية وشاقة وشبه منعزلة معتمدا على جمع والتقاط ما تجود به الطبيعة .وكان عدته وأدواته يسيرة من العظام وأغصـان الأثـجار لتأمين عيثـه ولحمايـة نفسـه مـن الأخطسار والتهديدات قبـل توصـله معرفـة صناعة أدواته مـن الحجارة (9'). اذ تم العثور على مخلفات ومـواد حضـارية كثيرة في العراء وكهوف المنطقة غالبيتها تضم أدوات حجرية خاصة بنشاطات الصيد .مما يشير الى ان الصيد كان نمطا أساسيا من أنماط الحياة الاقتصادية للجماعات البشرية الأولى في العصور الحجرية

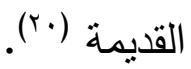

من الواضتح أن عصور قبل التاريخ قد شغلت القسم الأعظم من تاريخ البشرية ،عرف أقدم أزمانها باسم العصور الحجرية ،لذا أطلقت التسمية الحجرية على تلك الأزمان، لأن الانسان أعتمد على الحجر في صنع الآتة وأدواته البسيطة و أستتد الباحثون في تقسيم تلك العصور

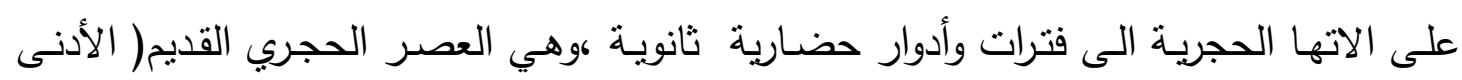
والأوسط والأعلى)، والوسيط والحديث ('r). وتميز كل عصر من تلك العصور بأساليب خاصسة من العيش والحياة الاقتصادية وبأثكال الآتها وأدواتها الحجرية المميزة (r؟r). 


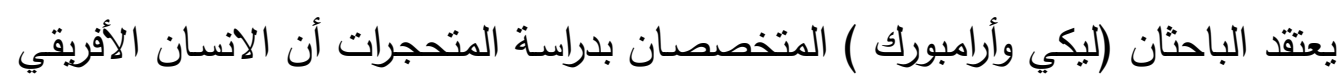

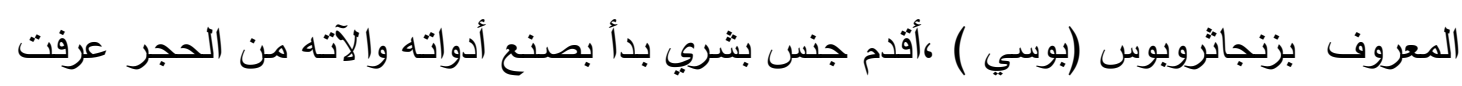

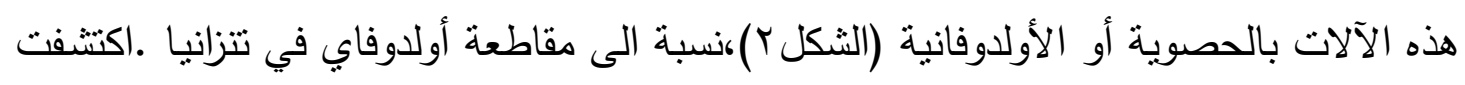

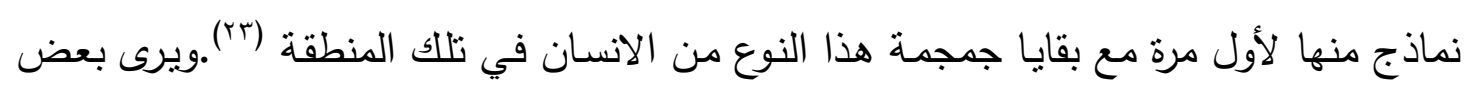

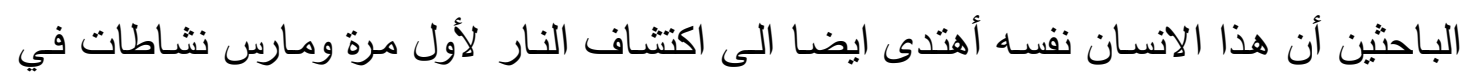

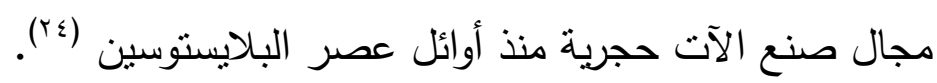

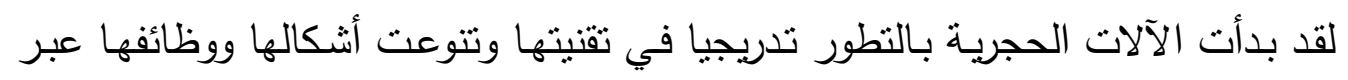

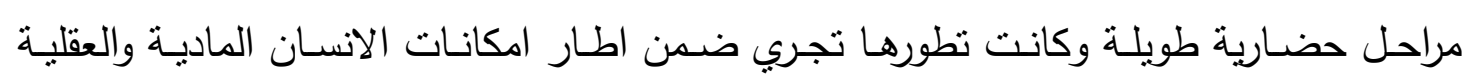

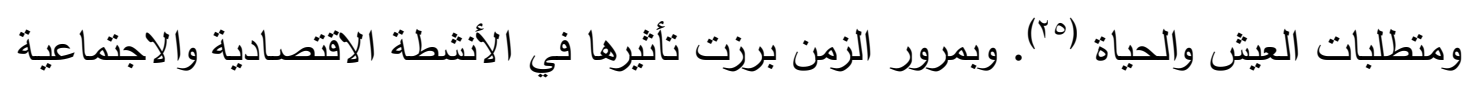

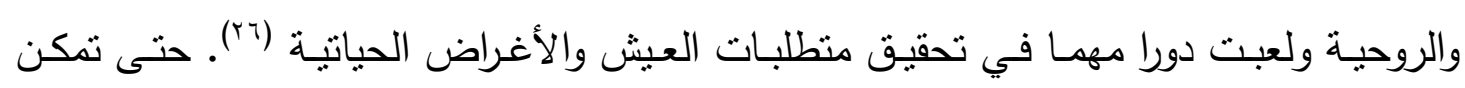

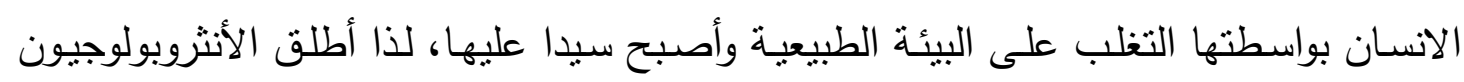
على الانسان مصطلح (صانع الآلة ) (rv).

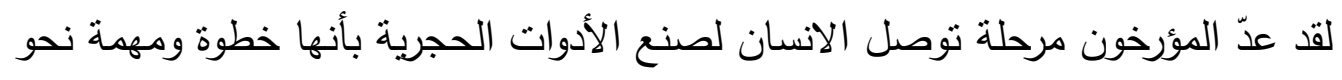

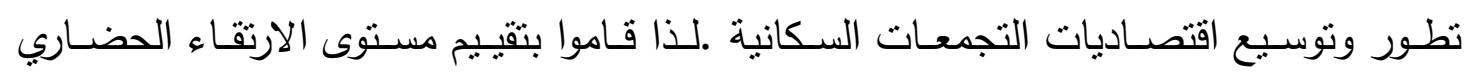

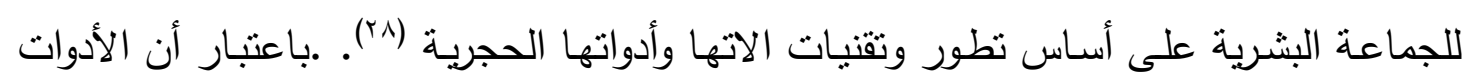

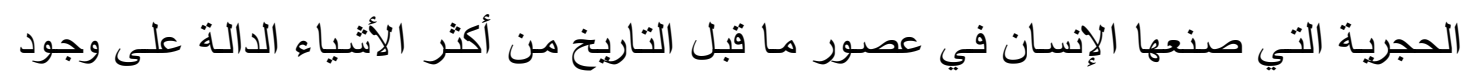

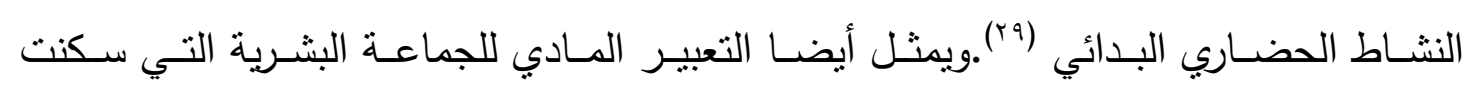

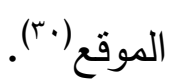

يستتج مما سبق أن الحضارات القديمة تدرجت في سلم تطورها في ظل بيئات جغرافية

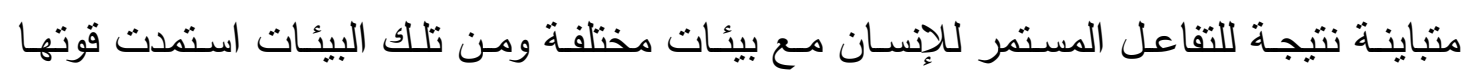

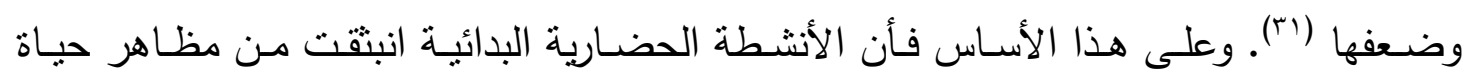

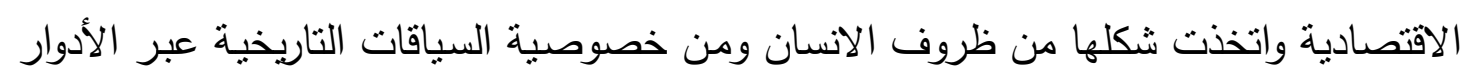

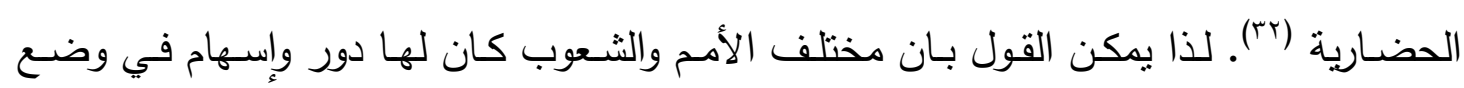
اللبنات الأولى للصروح الحضارية التي أحرزتها المجتمعات البشرية عبر السنين ،ولكن لم تكن

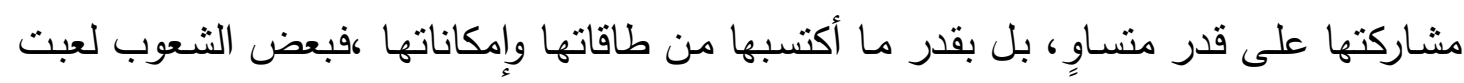

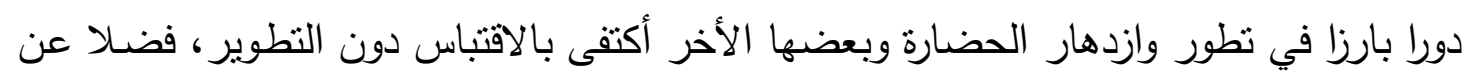
دور عوامل أخرى في نشوئها كالبيئة والاستقرار وغيرها (rr). 
النشاط الحضاري لأنسان كردستان في العصر الحجري القدبيم

\section{Lower Palaeolithic حضارة العصر الحجري القديم الأدنى(الأسفل)}

على الرغم من أننا لازلنا غير قادرين على التحدث بشكل واضـح ودقيق عن حضارة ما قبل التاريخ لأن معرفتتا للنشاط الحضـاري في العصر الحجري القديم الأدنى تعتمد على بقايا ماديـة مختلفة من الآلات الحجريـة كالفؤوس اليدويـة والثظايا والمقاشط وبقايـا عظام الحيوانات والنباتات وغيرها ، وهذه المخلفات الدالة على طبيعة حياة الانسان في هذا العصر لذلك يظهر لدينا ميل نحو خلط بين الحضارة والأدوات الحجرية (؟َ)وتميز هذا العصر بظهور نوع بدائي لآلات حجريـة عرفت ب( القتـرية) التي اعتمدت في أساسـها على استخدام التكنيك اللبي أو القشري للأحجار في صنع الأدوات الحجرية بطرائق ماهرة وتحويل نواة الحجر الى أشكال أخرى كالمقاشط وسكاكين وشظايا التي سميت بـالأدوات اللفالوازيـة والموستيرية (الثكل سأ) وهما من الن انجازات سكان الكهوف منهم انسان نياندرنال (ro). أظهرت الدراسـات والأبحاث الأثرية والجيولوجية وجود مخلفات أنسان الأول في سفوح جبال زاكروس وأجزاء دن السهول والهضاب و التلال المطلة على شمال شرق داقوق وجرمو في جمجمال وسهول ديانا ،ومواقع كهفية أخرى في سلاسل الجبال الواقعة ضمن منطقة رواندوز تعود للعصور الحجربة القديمة بسبب أرضـها خصوبة أرضـها وملاءمـة مناخها وبتوفر مصادر المياه فيها ، الأمر الذي شجع الصيادين على الانتشار وإقامهه مخيمات وقتية أثتاء بحثهم عن الحيوانات في تلك المناطق ،وهي نشكل نقطة انطلاق لتحضير الانسان نحو نشؤ نواة الأولى

لصروح الحضارة البدائية منذ العصور القديمة في هذه المناطق (بr). فقد قـام العـالم الروسـي (ن.ف.فافيلوف) المتخصص في عـم النبـات بدراسـة البيئات الطبيعيـة في امتدادات سلاسـل جبـال زاكروس وكوردستان . واظهرت نلك الدراسـة أن منطقة زاكروس من أفضل المناطق في الثرق الأدنى القديم التي تسودها ظروف مناخية ملائمة للنشاط البشري ولنمو النباتات البرية، مما أدت الى ظهور نواة الأولى للحياة المستقرة ،ولاسيما بعد بلوغ

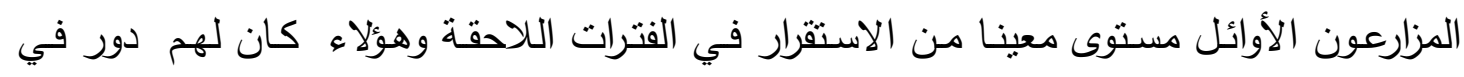
وضع أسس الحضارة الزراعية الأولى في سهول ووديان هذه المناطق (rv".

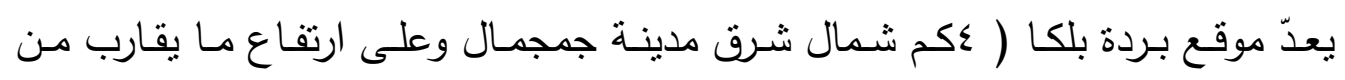

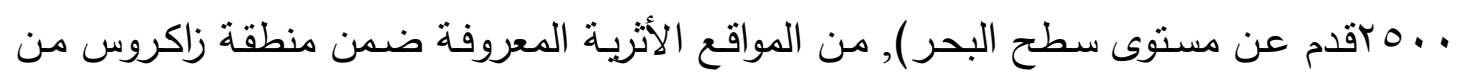
العصـر الحجري القديم الأدنى ،اكتشفت فيـه لأول مـرة اثنار وبقايـا حضـارية يعتقد أنها تمثنل

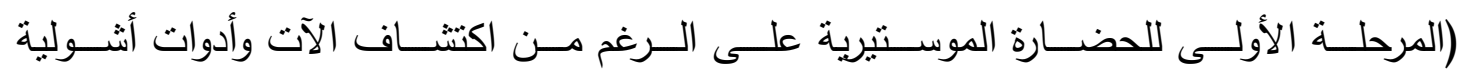
فيها (الثكل rب)، لذا (يعتقد بـأن المواد الحضـارية المكتشفة في بردة بلكا كانت مشتركة بين 


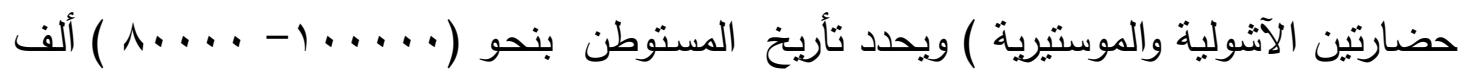

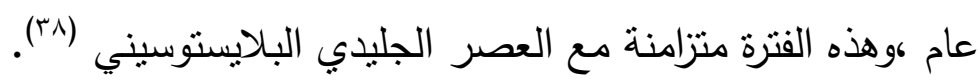
وتشـير الـدلائل الأثريـة أن الموقع سـكنه أنسـان نياندرتال ،كانوا يعيشـون على شكل جماعات غير مستقرة ومتجولين من مكان الى آخر سعيا للحصول على الغذاء .معتمدين في أقتصادياتهم على جمع البذور وجذور النباتات البرية وصيد الحبوانات من الطبيعة ، وهم بشكلون

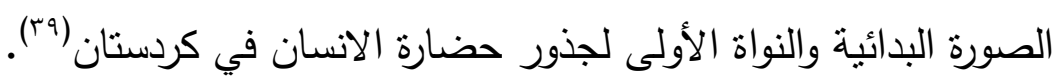

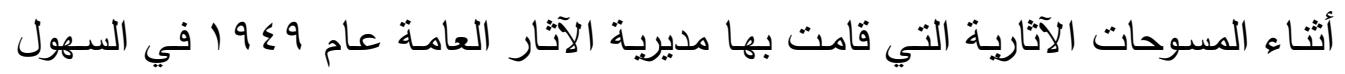
والتلال المحيطة بموقع بردة بلكا مثل (شيوة سور وباسـه رة ،رافدان رئيسان لنهر طـاوق جاي (نهر روخانه ) ،وجدت ملتقطات سطحية تمثل أدوات حجرية تضمنت أثكال مختلفة من فؤوس يدوية والآت قطع كالثظايا والسكاكين والمقاشط والمثاقب وهي تشبه في تقنيتها الأدوات الآشولية المصنوع وفق الطراز الموستيري المحلي (الشكلع)،وكان معظم الأدوات المكتشفة في الموقع تعود الى العصر الحجري القديم الأدنى.(•؛). فضـلا عن اكتشاف بقايـا عظام لحيوانات كبيرة وبرية كالثيران والفيل ووحيد القرن ،مما يدل على أن سكان هذا الموقع كانوا يعتمدون في عيشهم على صيد تلك الحيوانات (1). ولايزال موقع بردة بلكا يعدّ أقدم مستوطن بشري من العصر الحجري القديم ( مرحلة جمع

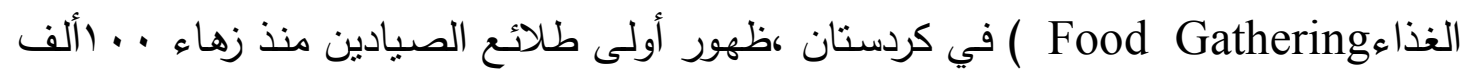
سنة وقدمت مكتشفات الموقع صورة واضحة عن التفاعل الإيجابي للإنسـان مع البيئة والتكيف

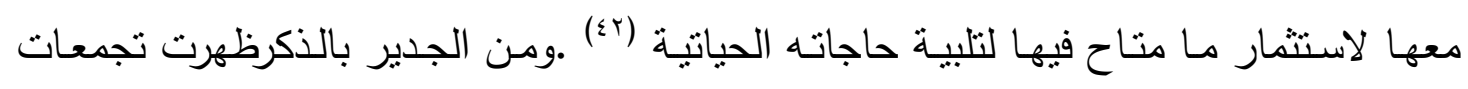
بشرية صغيرة وزمر غير مستقرة على شكل صيادين في مناطق مختلفة من العالم منذ العصور الحجرية القديمة، وكان كل فرد منهم يقوم بتتفيذ متطلبات واعمال وفق ما يراه ضروريا من أجل البقاء والعيش •وهذه الجماعات لم تكن لديها تتظيم اجتماعي ،ولكن كان الانسان بارعا وماهرا على الرغم من صعوبة حياتهم (rاء). لذا يمكن عد بردة بلكا المحطة الأولى للاستيطان في كردستان انبقت فيها الجذور الأولى للحضارة تطورت فيما بعد عبر فترات زمنية متتالية نقلت الانسان نحو آفاق أوسع وأكثر تطورا نتيجة لتضافرالثروط والمقومات الأساسية للحضارة في هذه المنطقة بسبب ملاعمة بيئتها الطبيعية ومـا توفره من التضـاريس والمنـاخ والموقع الجغرافي، فضـلا عن وجود مصـادر المياه وخصوبة الأرض والنشاط البشري (؛؛). تتضـح مما سبق أن الحضـارات البشرية منذ نشأنها الأولى قد مرت بعدة مراحل وأدوار ولكل مرحلة حضارية مقوماتها الخاصـة وطابعها المميز تتفرد بها عن غيرها من حيث الزمان 
والمكـان. ويـرى المختصـون أن الحضـارة الانسـانية كالكائنـات الحيـة تمـر بمراحل تطوريـة تبـدأ

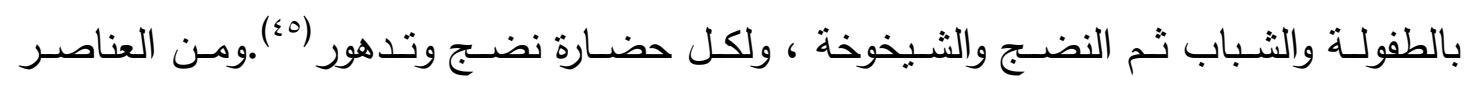
الأساسية للحضـارات القديمـة وهي الموارد الاقتصـادية والظروف الطبيعيـة والاجتماعيـة والنظم

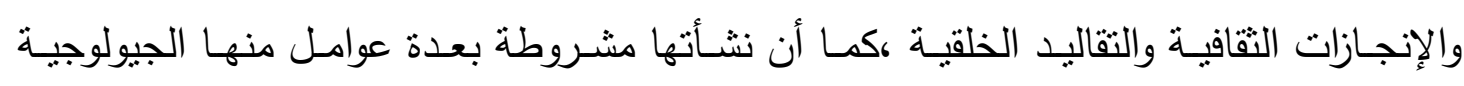
والجغرافية والاقتصادية (Tگ).

Middie Palaeolithic النشاط الحضاري لانسان نياندرثال في العصر الحجري القديم الأوسط وهن الحضارة الموستبرية - Mousterian ( . . . . . . . . . . . . ألف سنة):

تعدّ الحضارة الموستيرية أحدى المراحل الحضارية لعصور ما قبل التأربخ حصلت فيها

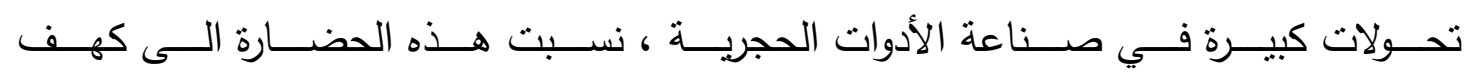
موستير (Moustier) الواقع في حوض ( الدور دون ) بفرنسـا ووجدت آثارهـا لأول مرة عام 9 . 9 1 في موستيرية، كما اكتتفت معالمها في بقاع كثيرة من العالم القديم منل ( بلجيكا وايطاليا

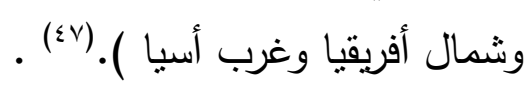
بدأت الحضـارة الموستيرية نزامنـا مـع ظهور الطلاكُع الأولى لإنسـان نياندرتال الــي

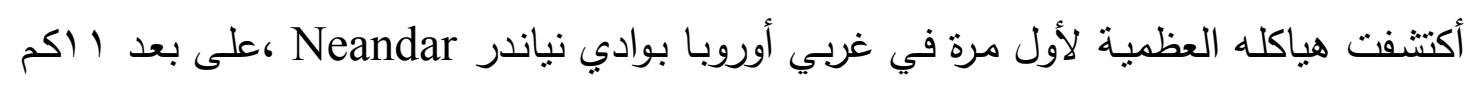
من دوسلدورف بألمانيا (^^الذا نسب الباحثون هذه الحضـارة الى هذا النوع من الجنس البشري الذي يحمل صفات فيزولوجيـة مشتركة بينه وبين الانسـان العاقل ،يمثل ظهوره مرحلة نطوريـة ضمن سلسلة المراحل التطورية التي مر بها الانسان.(9؛).). وتدل نتائج المسوحات والتنقيبات الأثرية الحديثة على انتشار الحضـارة الموستيرية في أرجاء واسعة من الثرق الأدنى القديم ،وفي العراق اكتشفت آثارها في عدة مواقع ،منها الأقسام

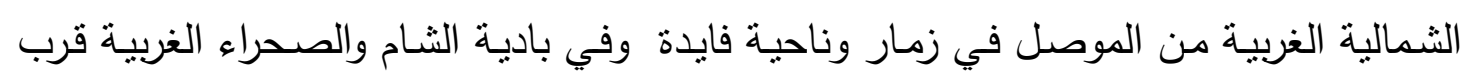

مدينة الرطبة و الرزازة وبادية السماوة وفي كهوف الطار بالقرب من قصر الأخيضر (.) أما في منطقة زاكروس فقد بدأت الحضارة الموستيرية بحدود ما يقارب من . ألف الف سنة وانتهى في حدود . . . . بألف سنة ،وشغلت معظم عصر البلايستوسين (10). وفي كردستان وجدت آثار لهذه الحضارة في عدد من كهوفها مثل ( شانيدروهاوديان وبيستون وبابخال في جبل برادوست وسبيلك وكهن حجية على روافد الزاب الأعلى القربية من بخمة ضمن حدود رواندوز

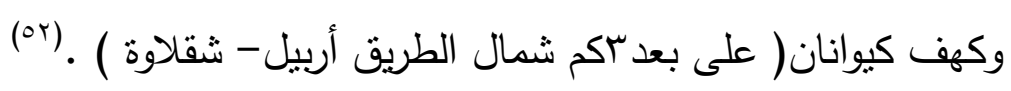

تميزت الحضـارة الموستيرية في مراحلها الأولى بتتوع الآتها الحجريـة وبأثكالها اليسيرة والخثنة وكانت معدولة من الحصى وحجر الصوان على شكل شظايا مدببة كمثاقب وسكاكين ومقاشـط أستعملها الصـيادون لقتـط جلـود الحيوانـات وقطـع الأخثـاب ،ومـرت هـذه الحضـارة بتحولات كبيرة في تصنيع الآلات والأدوات الحجربة التي صارت تشكل بأسلوب تشظية خاصسة 


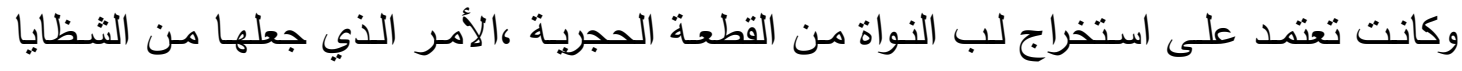

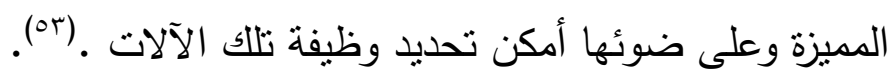

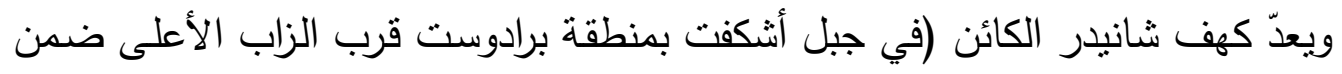

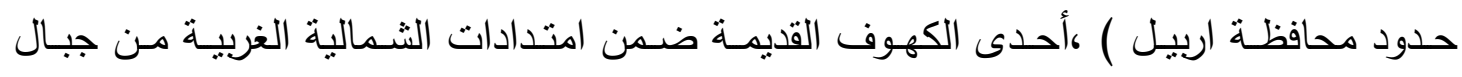

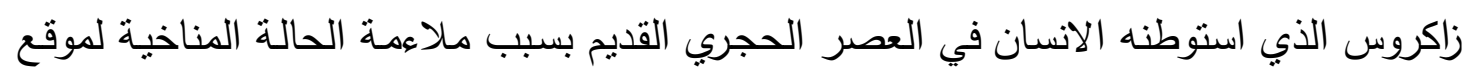

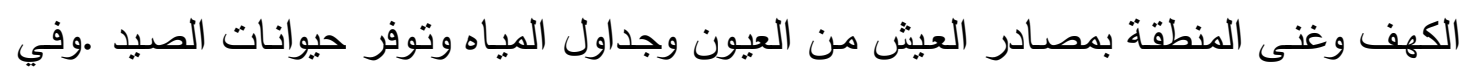

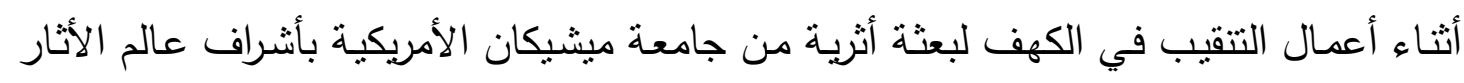

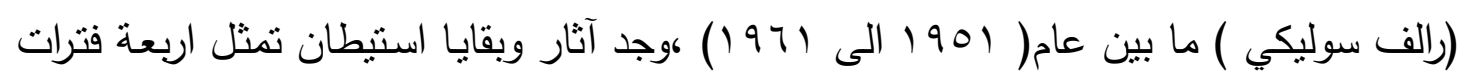
حضارية يرقى أقدمها الى احد ادوار العصر الحجري القديم المعروف باسم الدور الموستيري

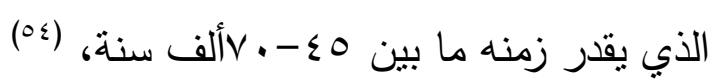

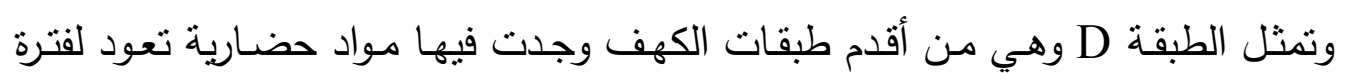

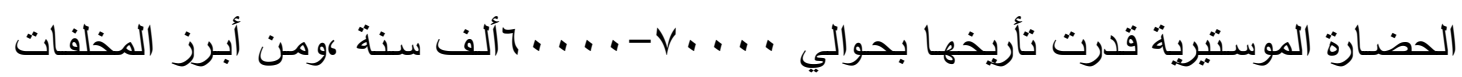

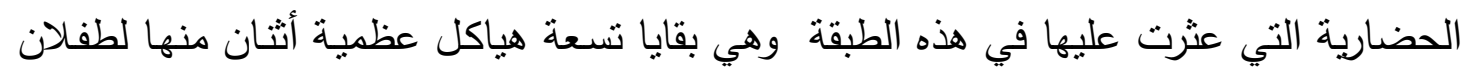

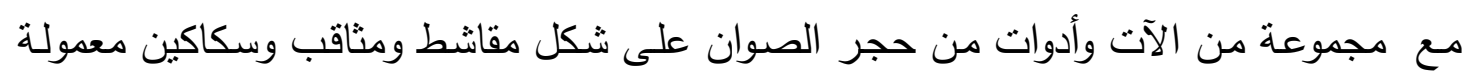

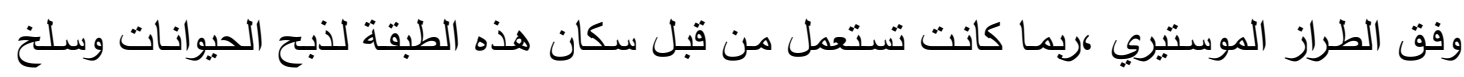

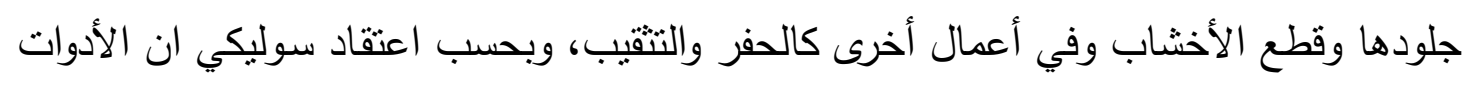

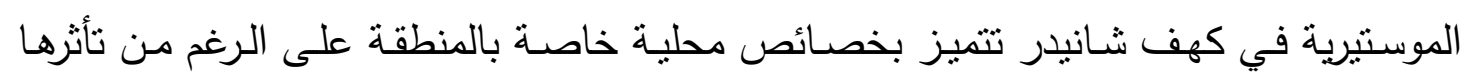

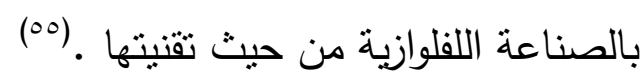

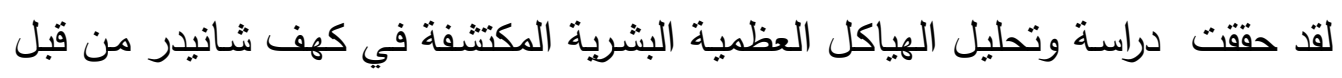

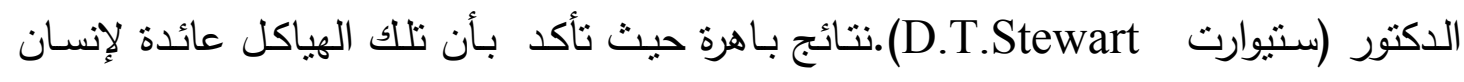

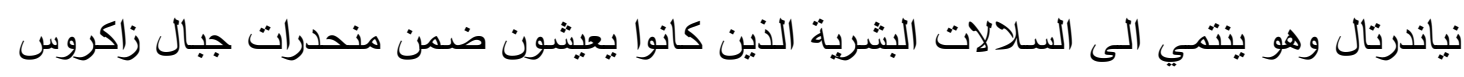

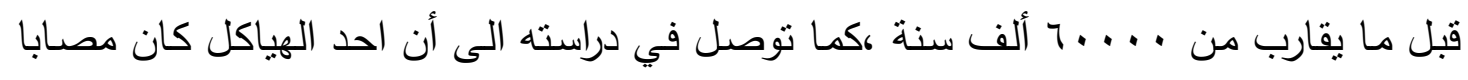

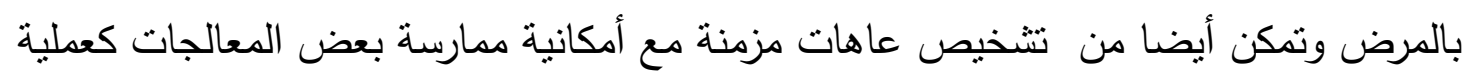

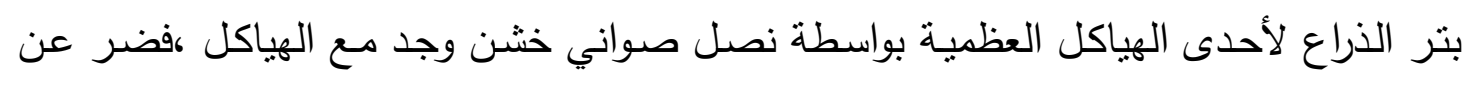

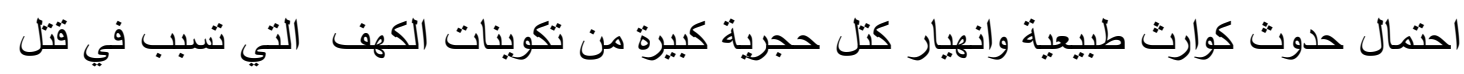

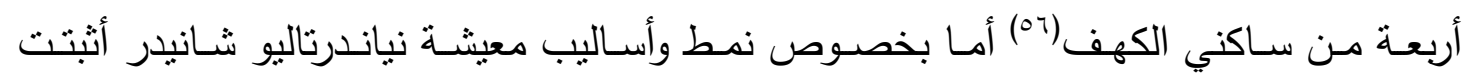

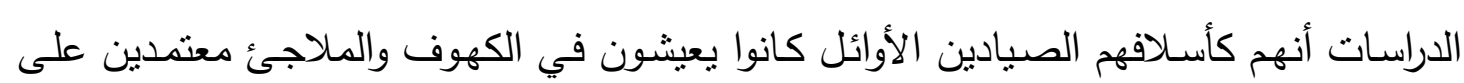
الصيد والطرائد .ويصنعون أدواتهم من الثظايا الحجرية تسمى بالأدوات الموستيرية (ov). 
وهكذا سـاعدت دراسـة الهياكل العظميـة المكتشفة في كهف شـانيدر على معرفة تأريخ

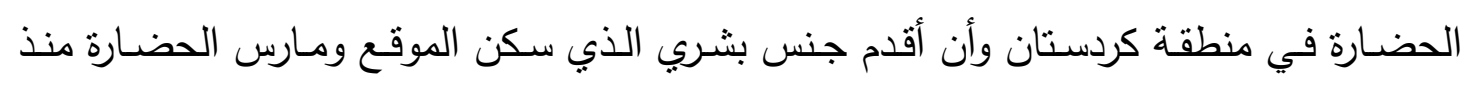

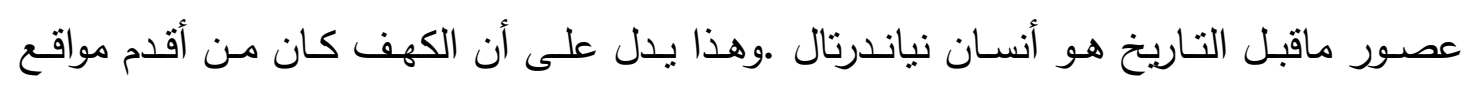

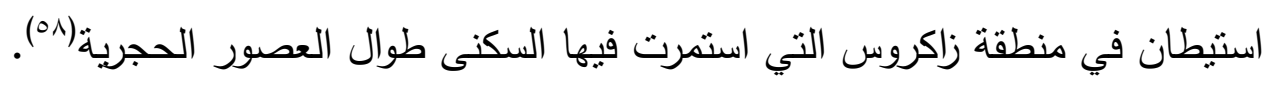

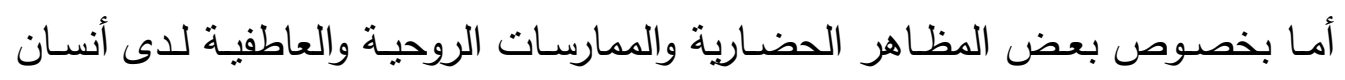

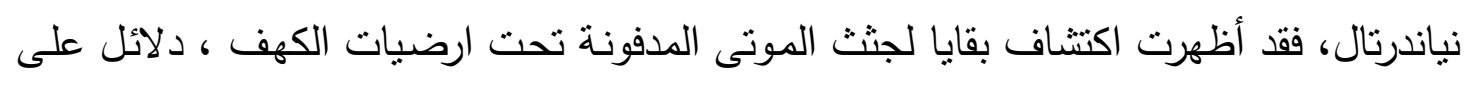

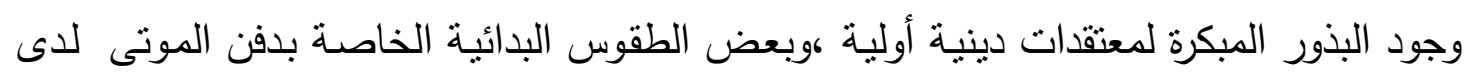

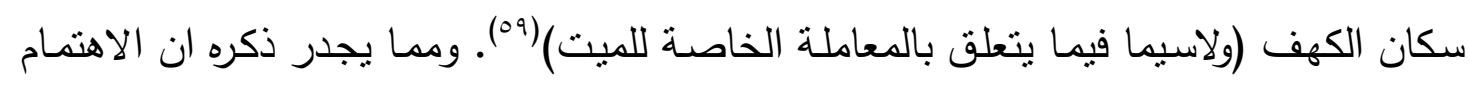

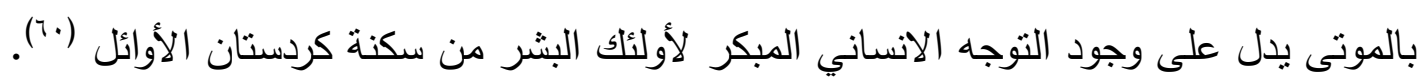

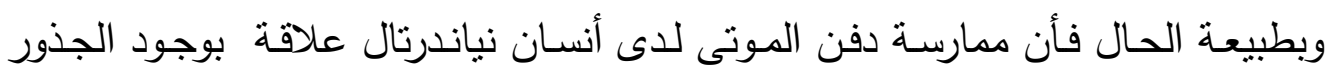

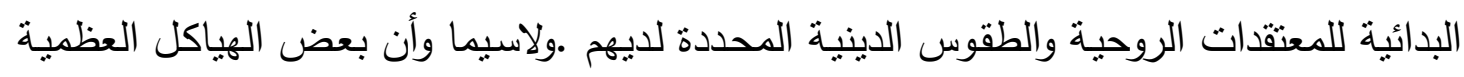

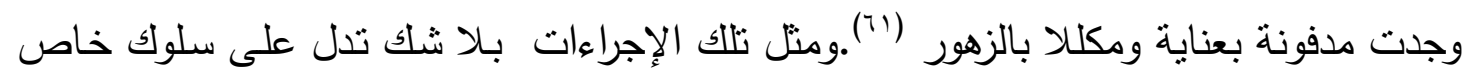

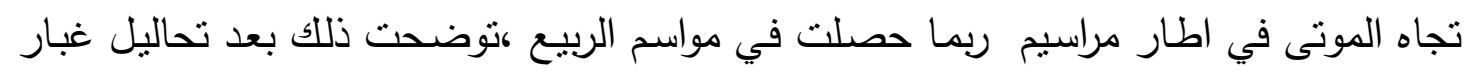

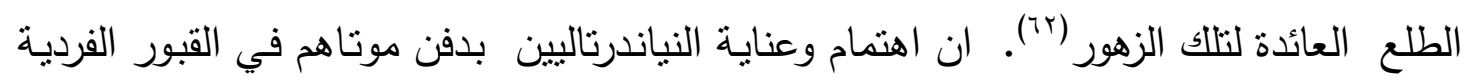

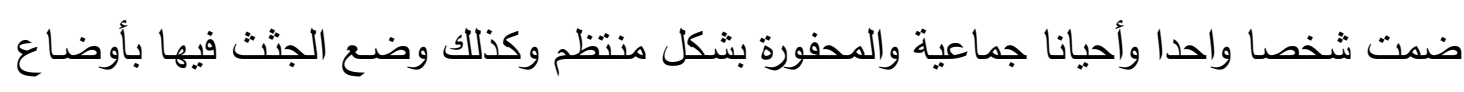

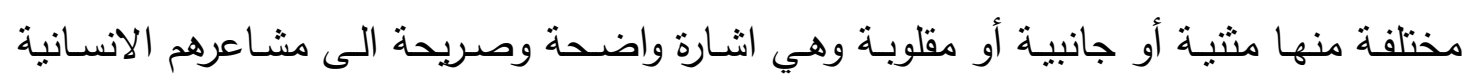
العميقة لموتاهم (Tr).

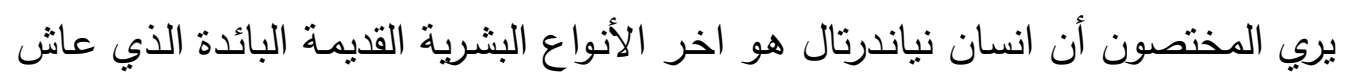

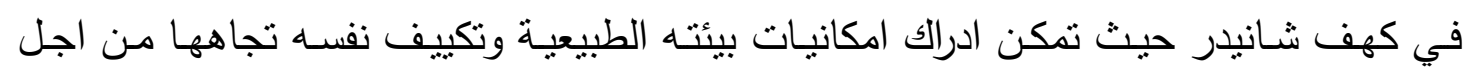

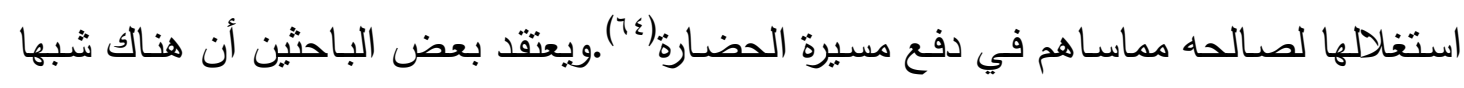
كبيرا بين انسان نياندرنال من شانيدر كردستان ونياندرنال المكتشف في جبل كرمل بفلسطين (70).

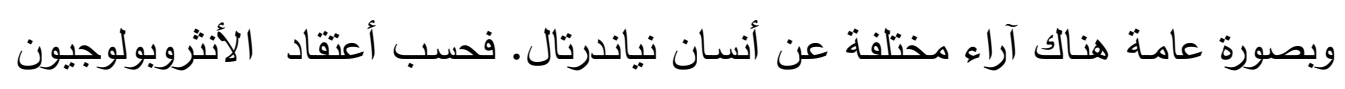

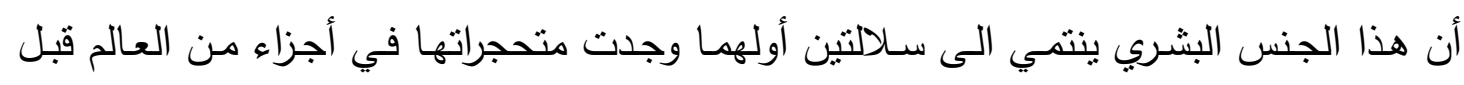

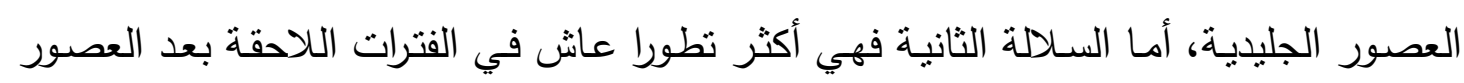

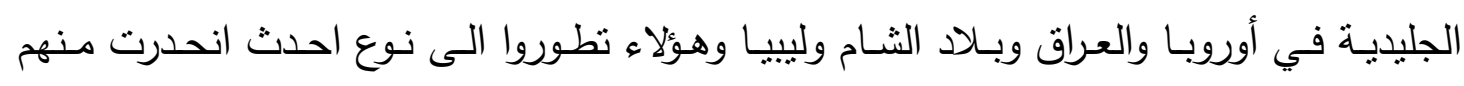

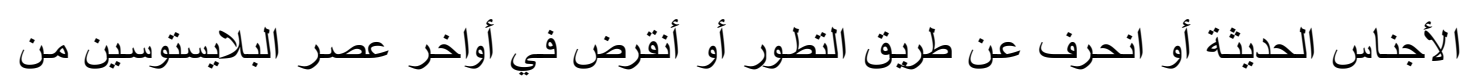

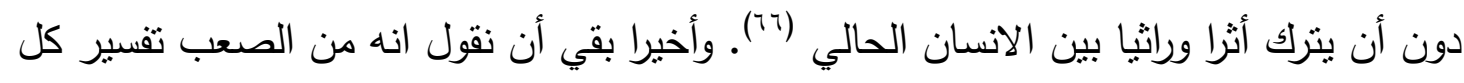

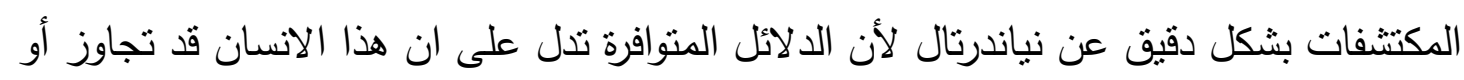

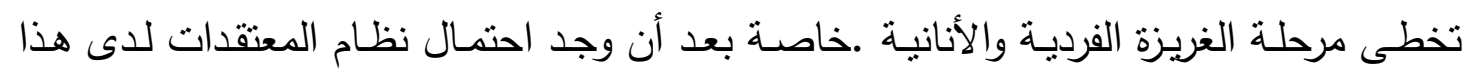
الانسان الذي يصعب تجاهله. 
والموقـع الثاني للحضـارة الموسـتيرية في كردسـتان بعد كهف شـانيدر ، كهف هزارمـرد

(9 اكم جنوب غرب مدينة السليمانية ضمن سلسلة جبال برانان) وهو موقع كهف ثان كثفت فيه الباحثة (دروثي كارود ) أثناء تتقيباتها عام 9 ( 1 ض ضمن بعثة أثرية أمريكية عن ثناثة أدوار

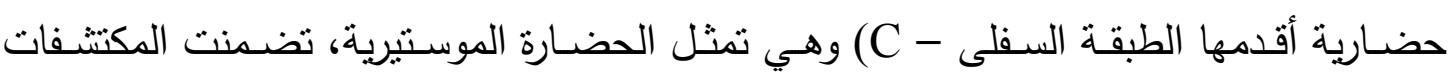
الحضـارية التي عثرت عليها في هذه الطبقـة على الآت وأدوات مـن حجر الصـوان منتوعـة

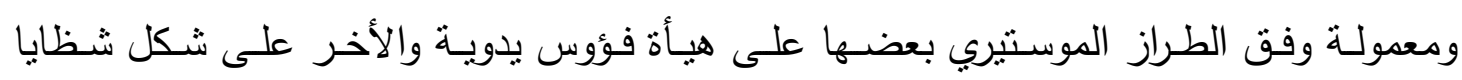
وسكاكين ومقاشط ومثاقب مع هياكل عظام تعود لأنسان نياندرتال. وهي تدل على أن الكهف هُ كان موقع سكني لهذا الانسان في تلاك الفترات (TV). وفي كهف بابخال شمال قرية هاوديان في منطقة رواندوز الذي يرتفع بحدود . . مr قدم عن مستوى سطح البحر .عثرت البعثة الأثرية التي كانت تقوم بأعمال التتقيب في جرمو برئاسـة (بريدورد) على الآت وأدوات حجريـة من طراز الموستيري في الكهف مشـابهة تمامـا من حيث تقنيتها وأثكالها بصناعة الآلات المكتشفة في كل من بردة بلكا وهزارميرد (الطبقة C) والطبقة (D) في شانبدر (D)

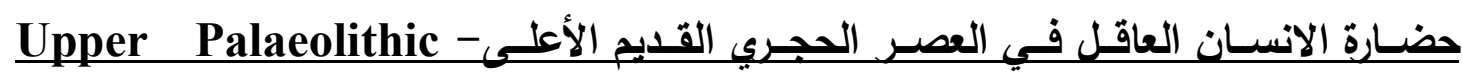

(1)

الحضارة الأورغنيشية والبرادوستية

يعدّ العصر الحجري القديم الأعلى مرحلة حضارية مهمة والذي شغل النصف الثاني من دهر البلايستوسين. يقع زمنه في نهاية العصر الجليدي الرابع المسمى (ورم ) في أوروبا وقدر

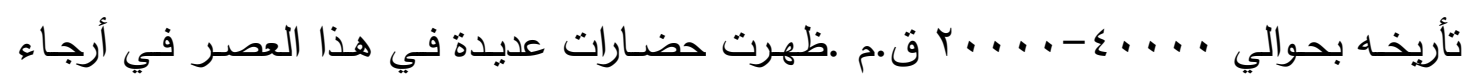

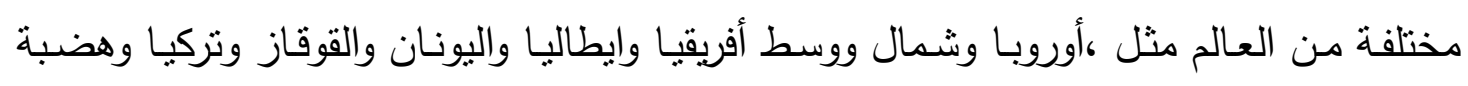
أيران والعراق ومصر حتى وصلت سواحل المحيط الأطلسي. اكتشفت آثار الحضارة الأورغنيشـة لأول مرة عام • 1 1 م من قبل الباحث (لارتيه )في موقع أورنياك جنوب فرنسا ، وتمثل هذه

الحضارة مرحلة انتقال من العصر الحجري القديم الأوسط الى الأعلى (79) .

أطلقت على هذه الحضارة تسميات مختلفة باختلاف المواقع والمناطق التي وجدت فيها . ففي شمال أفريقيا عرفت بالحضـارة الققصية والوهرانية وفي مصر بالحضارة السبيلية (نسبة الى

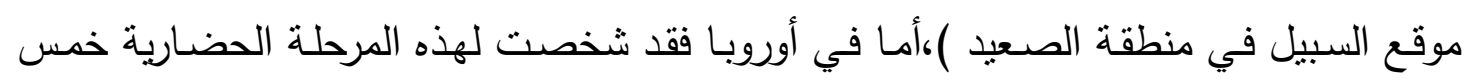

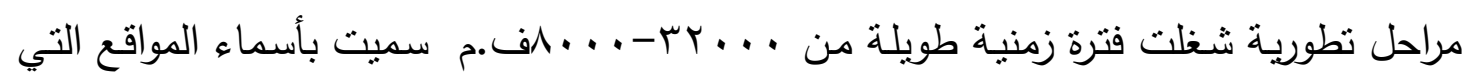
تطورت فيها وهي كالآتي : بريكودي سثاتل بيروني وأورغنيشي وكرافيتي وسلونري ومكدليني (•). 
وفي كردستان وجدت آثار للحضارة الأورغنيشية في الطبقة C من كهف شانيدر ، أطلاق

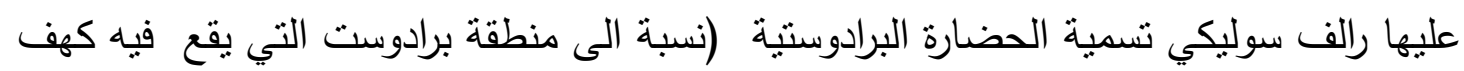

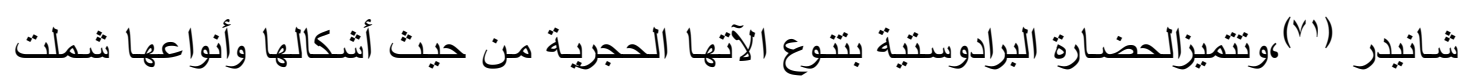
الآت صوانية على شكل شفرات دقيقة وبسيطة ومحورة كالمعاول والمزارف والمقاشط وأحجار التهار

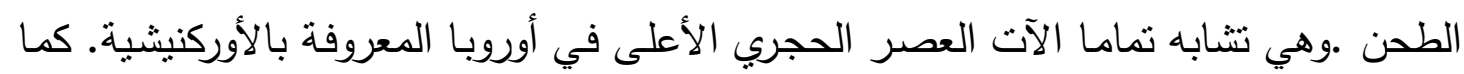

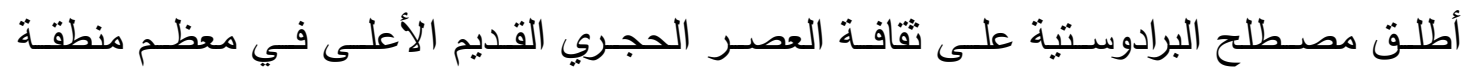
زاكروس (Vr) (

ففي كهف زرزي ( •0 كم شمال غرب السليمانية ) كثفت الباحثة دروثي كارود اثناء تتقيبها في الطبقة C من الكهف آثار للحضارة البرادوستية شملت الآت حجرية متخصصة ومنقنة

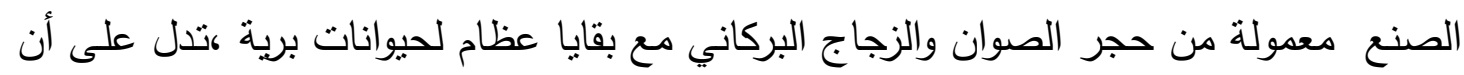

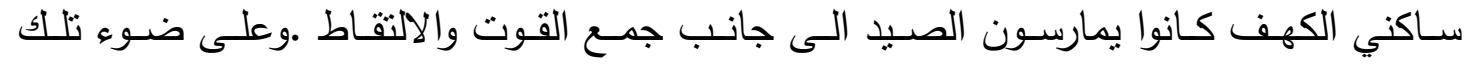

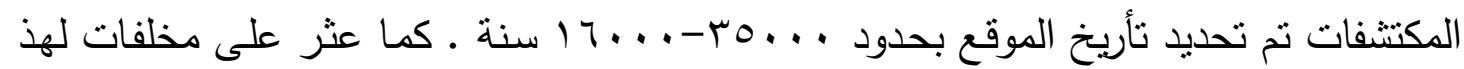
الحضارة في كهف بالي كورا بالقرب من (مضيق دربند بازيان ضمن امتدادات سلسلة جبال

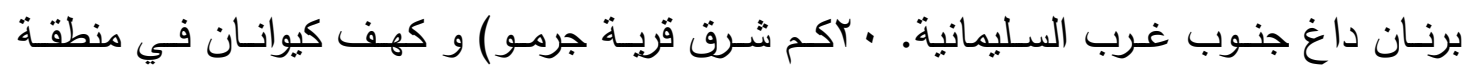

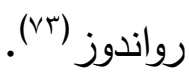

من أبرز المظاهر الحضارية لهذه الفترة حصول تطورات وتبدلات جذرية ونوعية في تقنية وطبيعة الآلات والأدوات الحجرية من حيث النتويع والتكنيك مع تطور في أساليب التشظية التي امتازت بدقة صنعها وإتقانها وصغر حجمها وبتخصصها وتتوع في استعمالاتها الوظيفية

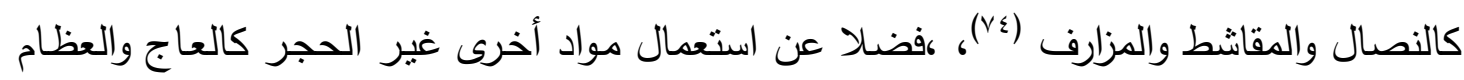

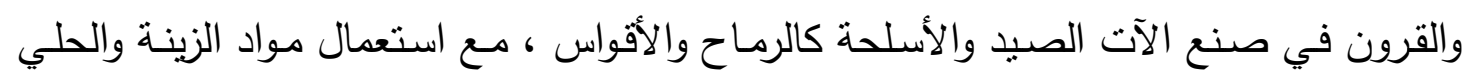

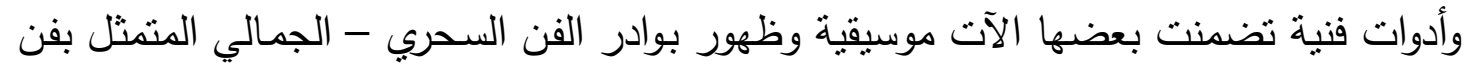

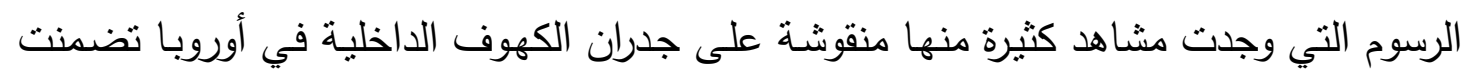

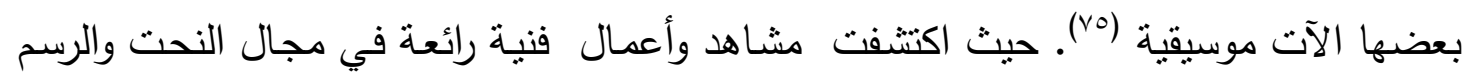
والنقش وهي تجسد مشاعر الانسان ومعتقاته في كهوف والنلاجي الصخرية في مناطق مختلفة

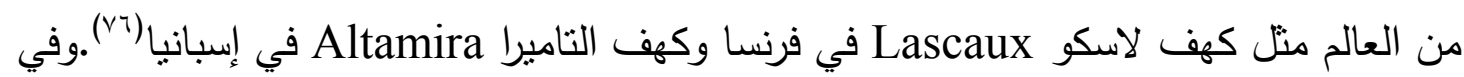

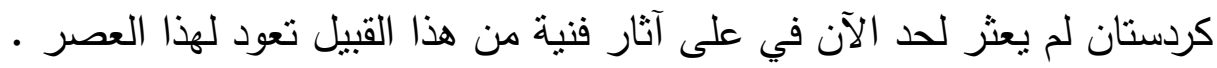

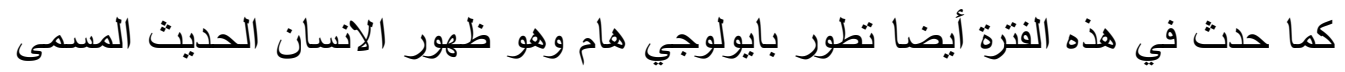

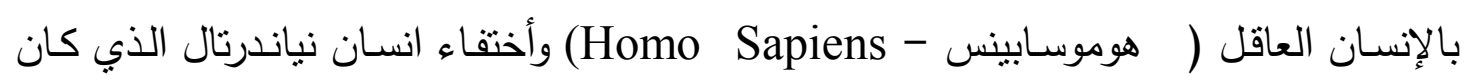
سائدا في العصر الحجري القديم الأوسط (الفترة الموستيرية ) ـ لذان نسب الباحثون الحضـارة 
أ.م. د. نعمان جمعة ابراهيم

منجزات انسان عصور ما قبل التاريخ في كردستان العرلق ومظاهر حضارته حتى نهاية العصر الحجري القديم الأعلى فئى الأورغنيشية الى (هوموسابينس) وعددها من انتاج هذا الانسان الذية الذي أكتشف بقاياه لأول مرة

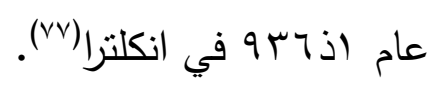

أظهرت المسوحات الأثرية الأخيرة أن منطقة زاكروس انتشرت فيها الحضارة البرادوستية

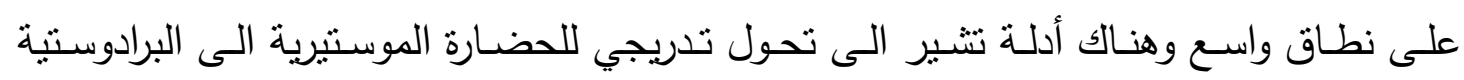

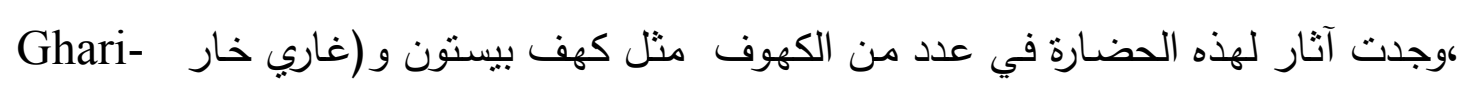

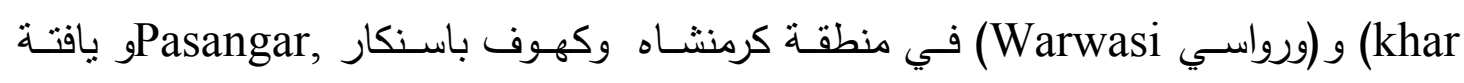

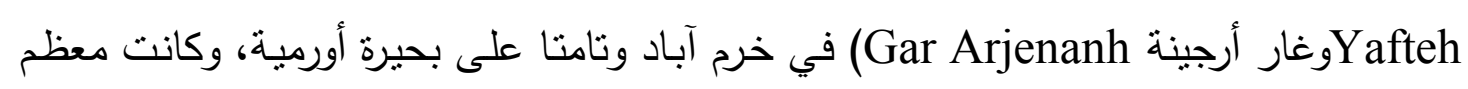

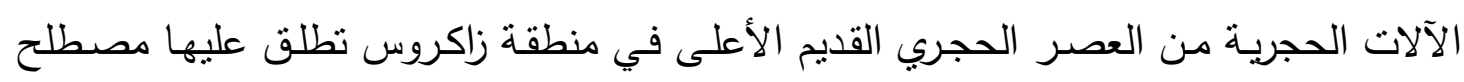

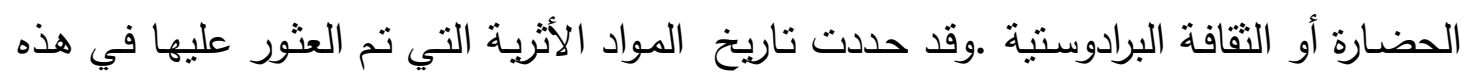

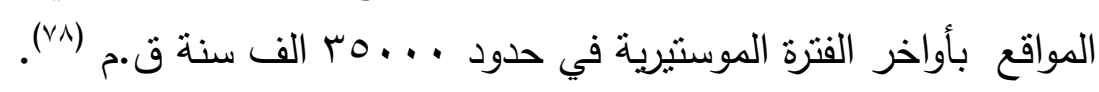

\section{الحضارة الزنزية:}

في أواخر العصـر الحجري القديم الوسيط(Mesolithic) شـهدت أجزاء مـن الثـرق

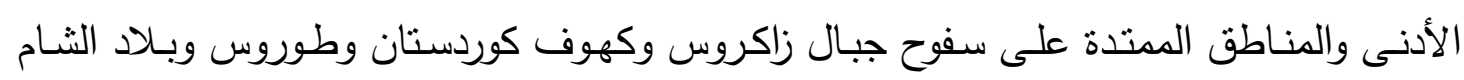

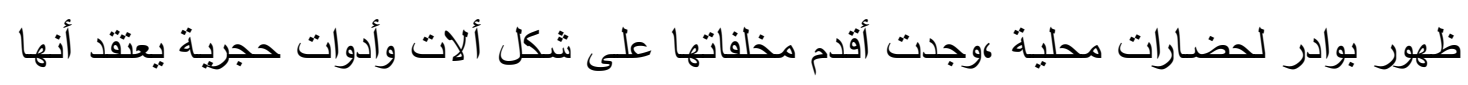

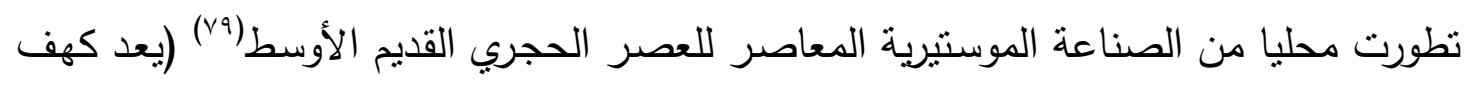

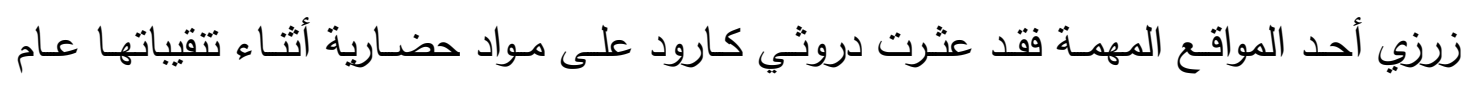

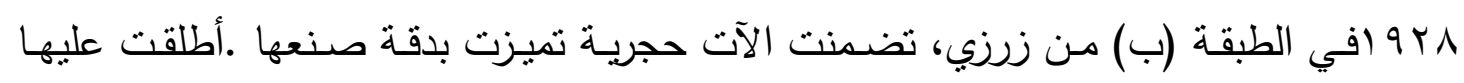

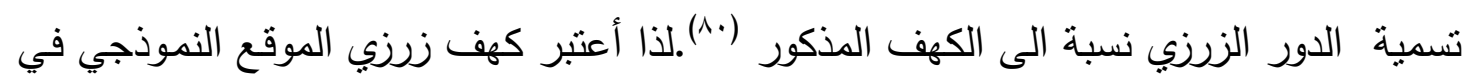

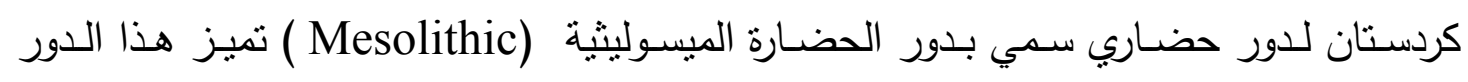

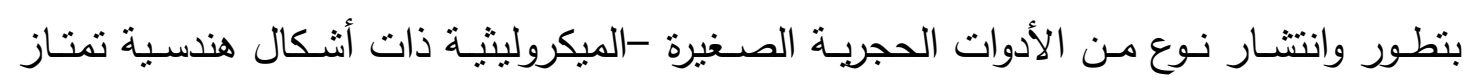
بتقنيتها ودقتها وصغر حجمها أنتجتها حضارات عدة في أزمنة وأمكنة مختلفة (الثكله) (1).

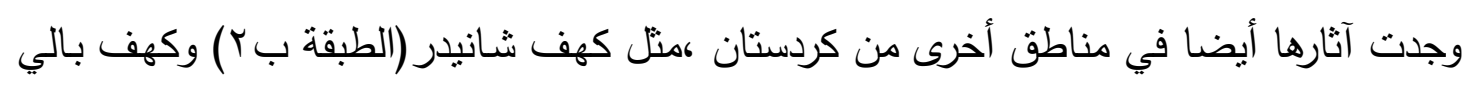

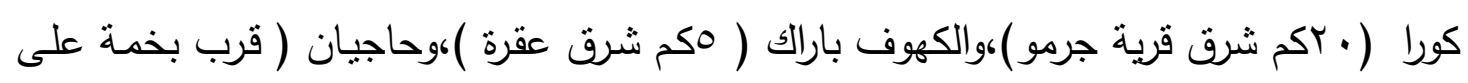

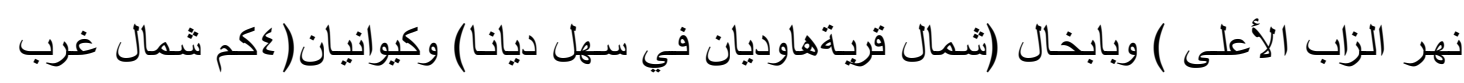

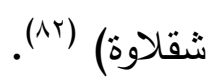

وانتشـرت تقاليد حضـارية مشـابه لدور ز زرزي في بعض المنـاطق الأوربيـة والأفريقيـة

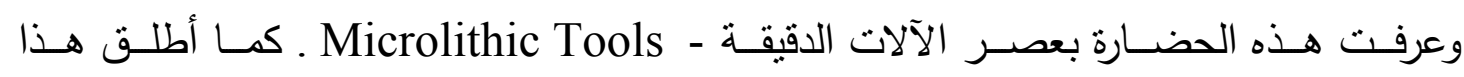
المصطلح أيضـا على أغلب الأدوات الحجريـة التي عثر عليها في منطقة زاكروس الثرة الثمالية 


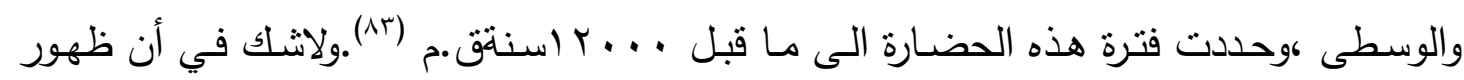
الحضارة وتطورها في كهف زرزي في هذه المرحلة ، يعود الى توفر المصادر الرئيسة للعيش

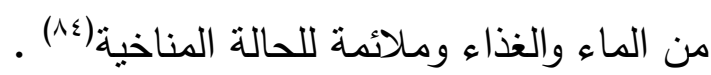

يمثل دور زرزي مرحلـة انتقال مـن الصيد وجمـع القوت الـى مرحلـة الرعي والزراعـة التجربيية ،أذ حصل فيه تحول في حياة الانسان من مرحلة السكن في الكهوف الى الاستقرار في

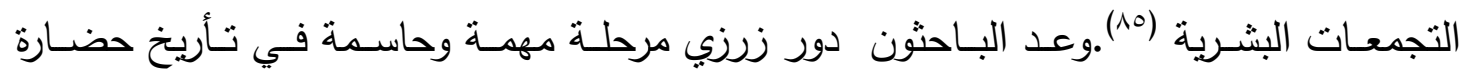
المنطقة، كونها حملت دلالات تشير الى حصول تطورات وتبدلات جوهرية في حياة الانسان من النواحي الفكرية والاقتصادية و الاجتماعية (זن).

\section{الاستنتاجات}

وفي الختام وبعد أن وصلنا الى نهاية البحث يتضح لنا ما يأتي :1- منطقة كردستان مازالت بحاجة الى المزبد من الدارسات والبحوث والاستكثافات الأثربة ، ولاسيما عن ظهور الانسان ومظاهر حضارته . ץ- تدل المعطيات الأثرية على أن منطقة كردستان قد استوطنت بشكل كثيف أبان العصور الحجرية القديمة منذ زهاء . . . . . ألف عام.وكل المؤشرات توحي الى أن منحدرات جبال زاكروس (كردستان ) قد مرت بسلسلة من التحولات الأساسية منذ المراحل الأولى لظهور الانسان فيها وحقق إنجازات وتحولات كبيرة .كان للمنطقة النصيب الأوفر في ابتكار ونطوير الصناعات الحجرية، أذ شهدت هذه المنطقة الانتقال الحضاري المبكر في تأريخ البشرية المتمنل بتطوير النظم والأنشطة الاقتصادية والاجتماعية . ץ- كان لتتوع التضاريس و تباين مظاهر سطح أرض كردستان أبلغ الأثز في سير نأريخها وفي وضع أسس وقواعد الحضارة بسبب التقاعل المستمر بين الانسان والبيئة عبر الأزمنة الطويلة.

ع- تبين لنا من الشواهد والقرائن ان الأدوات الحجرية كانت من أهم الآثار المادية وأوسعها وأكثرها انتشارا أعتمد عليها الانسان في صنع الاته ومستلزماته في مجالات وانشطة مختلفة ،كانت لها دور في مقاومة عوامل الفناء بخلاف بقية المواد الأخرى التي أتلفها - الزمن

ه-برهن الاكتشافات الأثرية ان أقدم مهنة مارسها الانسان منذ عصور ما قبل التاريخ هي صناعة الآلات والأدوات الحجرية .وتطورت هذه المهنة بشكل تدربجي استغرقت الآلاف السنين. تميزت بتقنياتها وأصبحت أساسا لتميز ومعرفة تأربخ مجتمعات ما قبل التاربخ 
أ.م. د. نعمان جمعة ابراهيم

منجزات انسان عصور ما قبل التاريخ في كردستان العلق ومظاهر حضارته حتى نهاية العصر الحجري القديم الأعلى فئى

وطبيعة حضاراتها، مما أعطى دلالات زمنية وحضارية كبيرة وعلى أساس دراستها

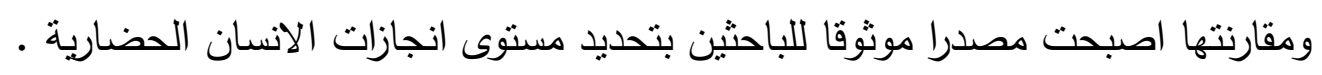

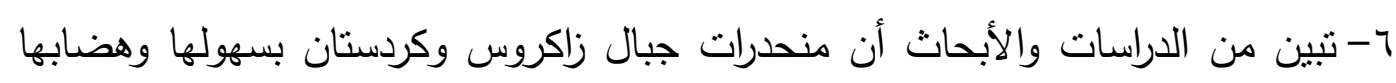

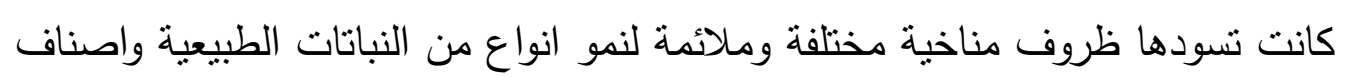

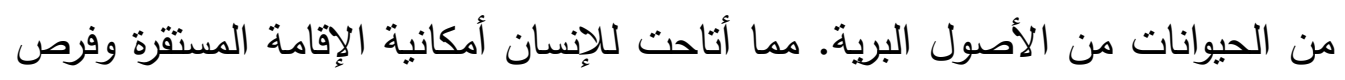

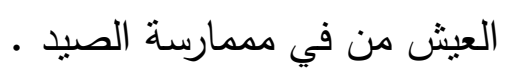

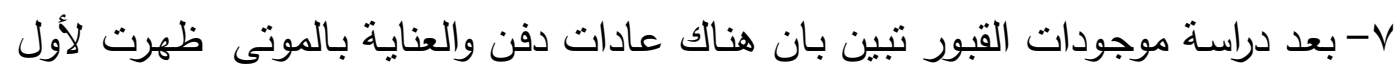

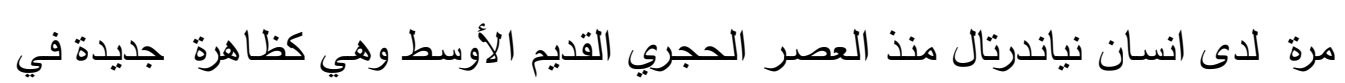

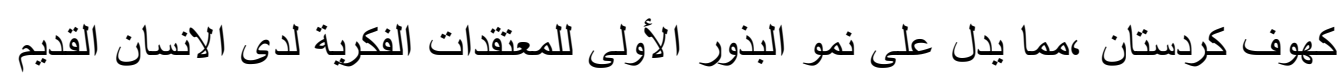
في هذه المنطقة . 


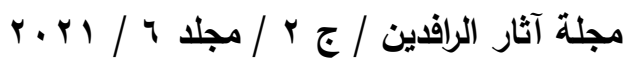

الأشكال

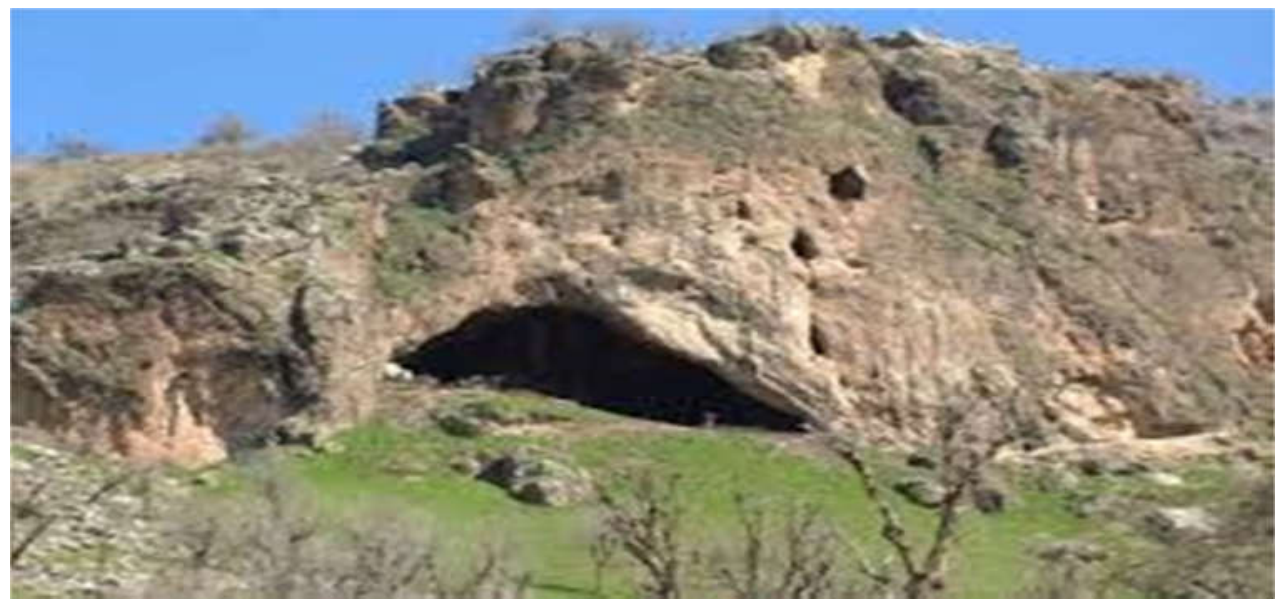

الشكل - 1 -منظر امامي لكهف شانيدر شمال شرق أربيل
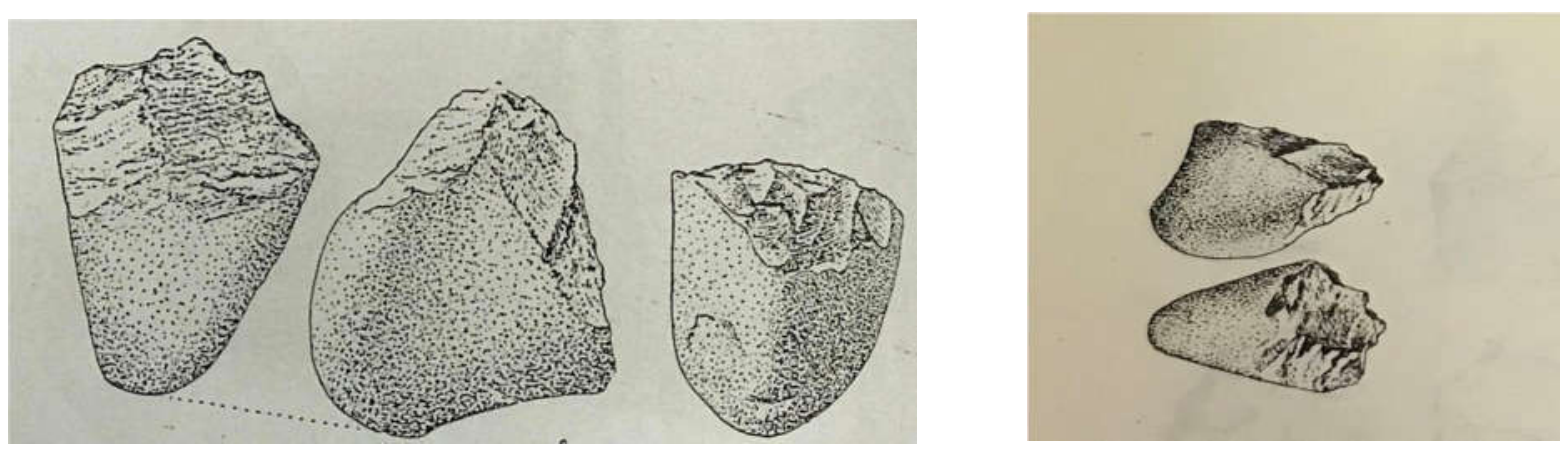

$$
\begin{aligned}
& \varphi
\end{aligned}
$$

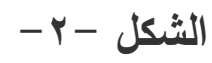

$$
\begin{aligned}
& \text { نماذج من الأدوات الحصوية من اولاوفاي }
\end{aligned}
$$

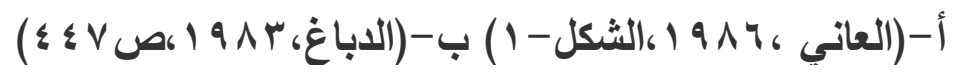




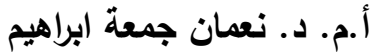

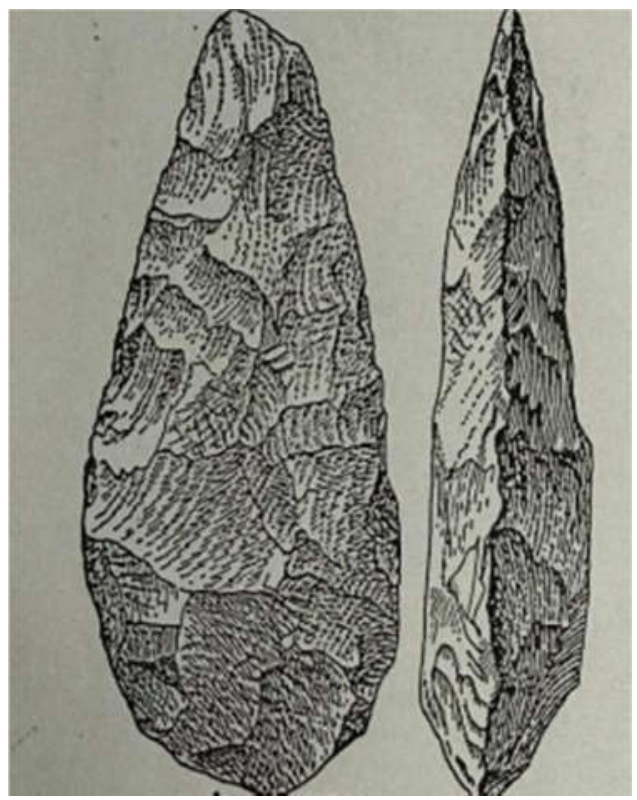

$$
\varphi
$$

منجزات انسان عصور ما قبل التاريخ في كردستان العرلق ومظاهر حضارته حتى نهاية العصر الحجري القديم الأعلى

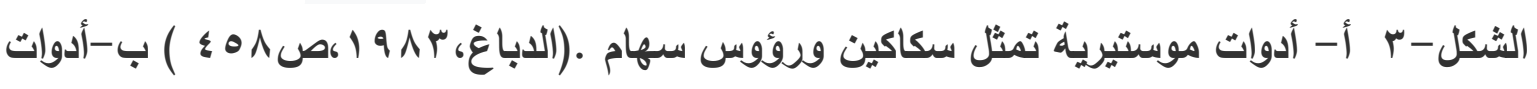

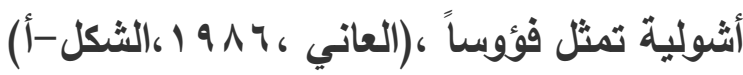
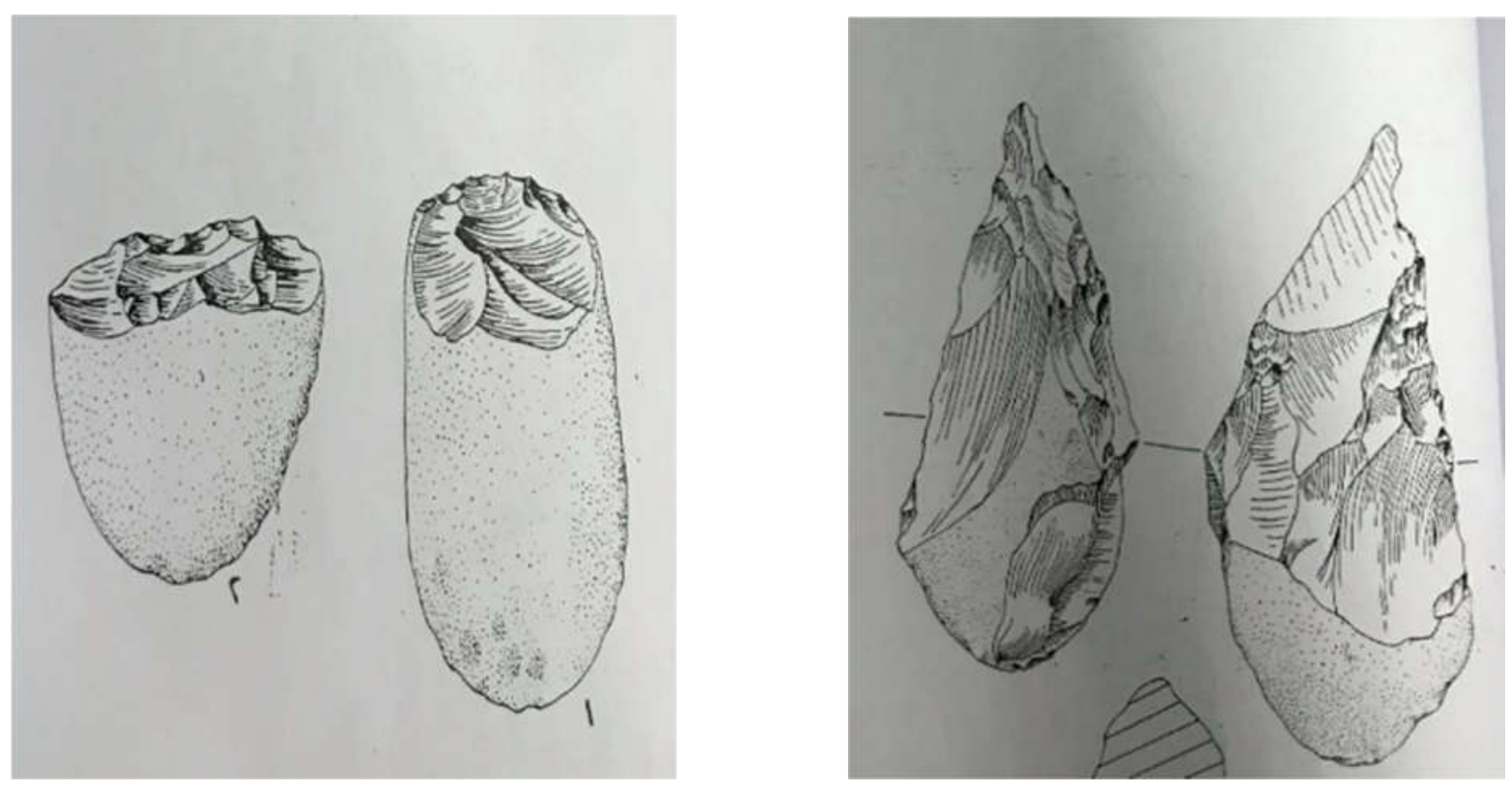

الثكل- ـ - فؤوس حجرية من بردة بلكا.العصر الحجري القديم الأوسط

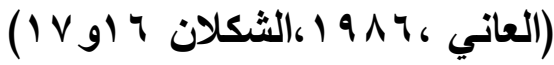




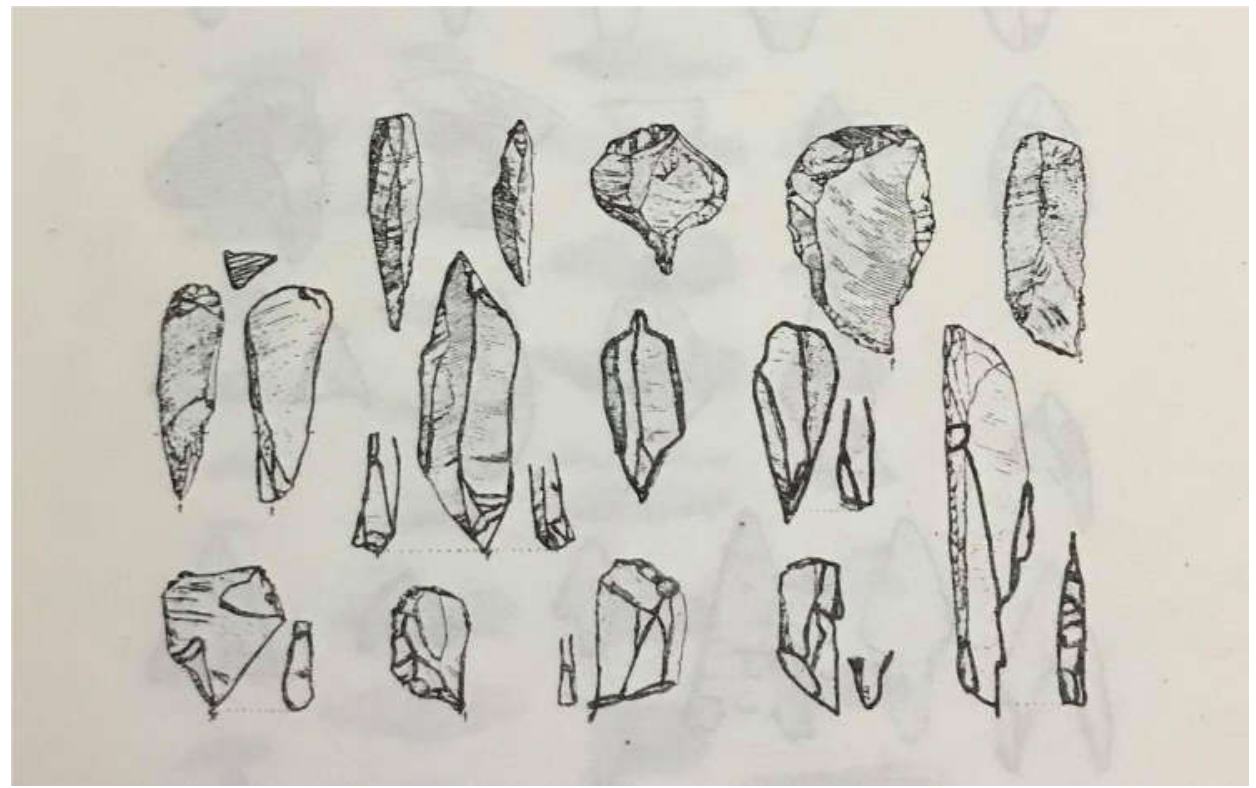

الثكل -ه - ادوات حجرية مايكروليثية اكتثفت في مواقع مختلقة من اوريا

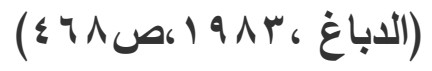

الهوامش

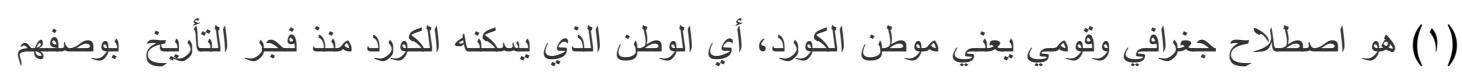

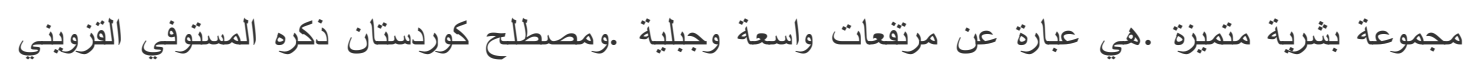

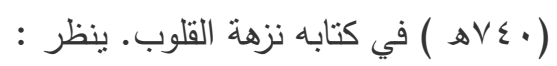

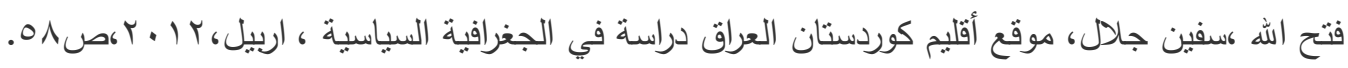

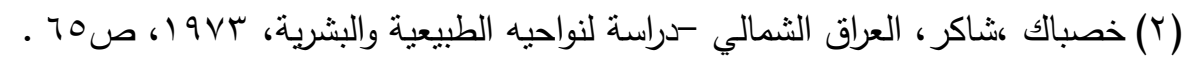
وأيضا:

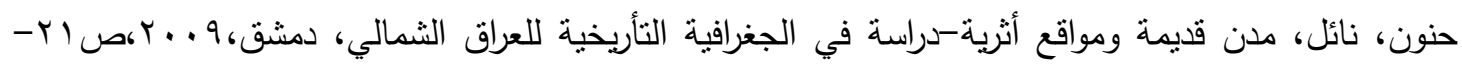
.rV

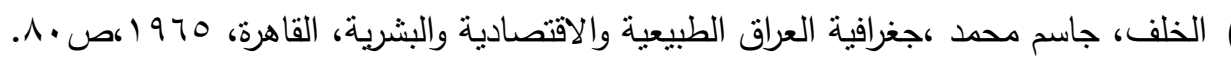

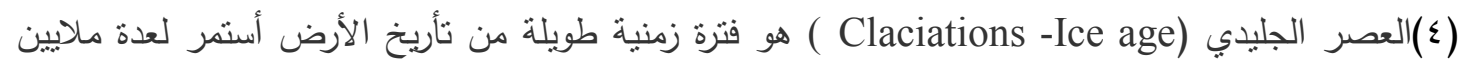

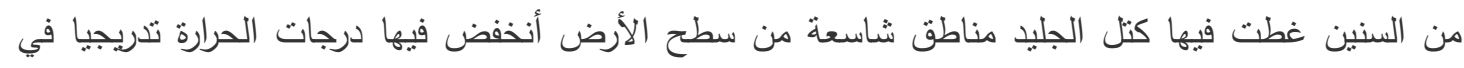

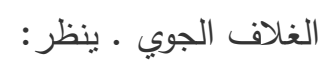

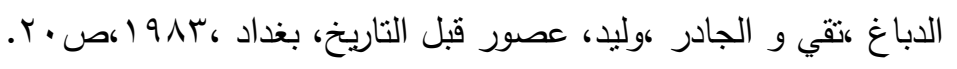

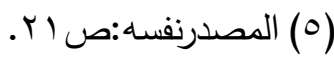

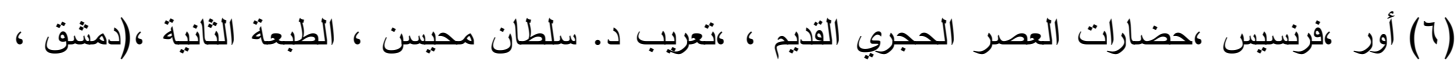

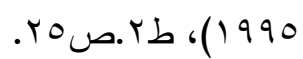

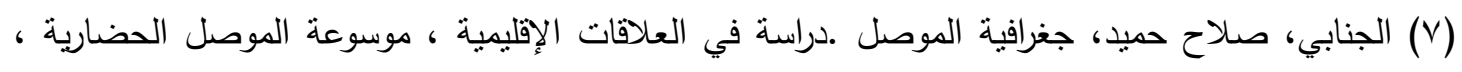

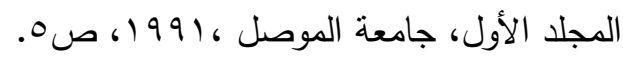
(^) الثيخلي ،عبد القادر عبد الجبار، الدذل الى نتأريخ الحضارات القديمة .القسم الأول، بغداد ،.999 199، 
(9) هـ .آ، رايت، العصر الجليدي البلايستوسينى في كردستان، نرجمة فؤاد حمه خورشيد، بغداد ،1917، 194

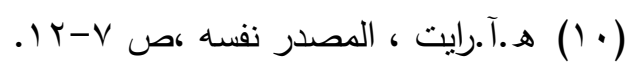

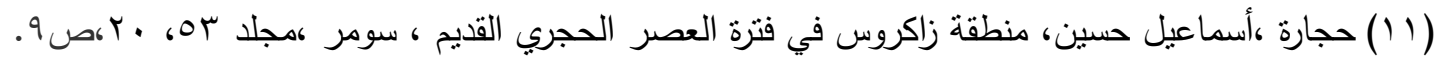
(12) Braidwood,Robert.J. And How Bruce.Prehistoric Ivestigations in Iraqi Kurdistan.Chicago.1960.pp.171-172.

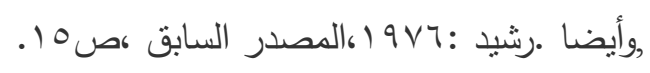

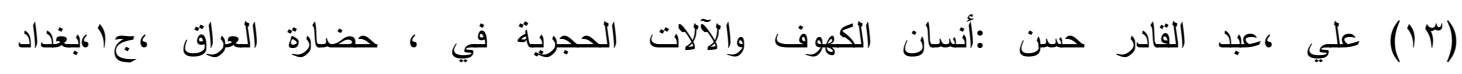
.VA1910،

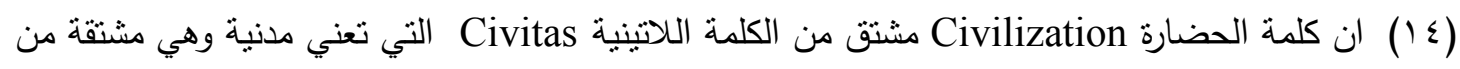

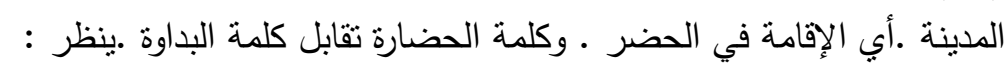

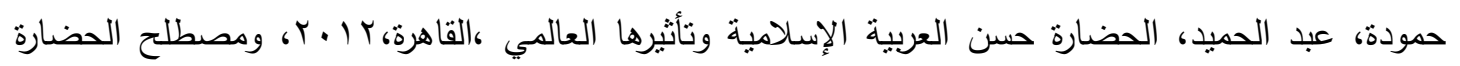

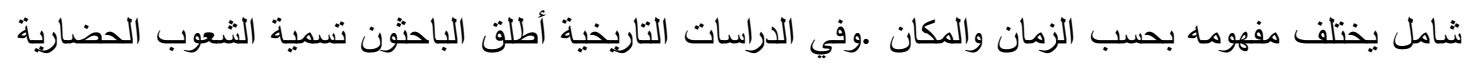

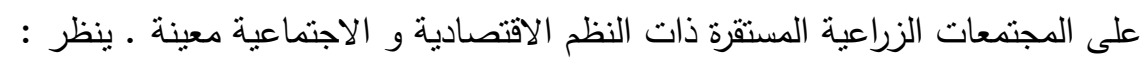

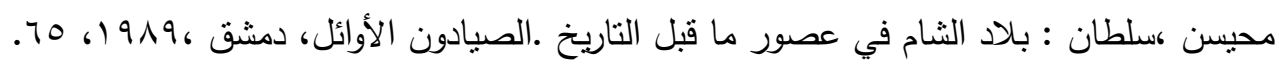

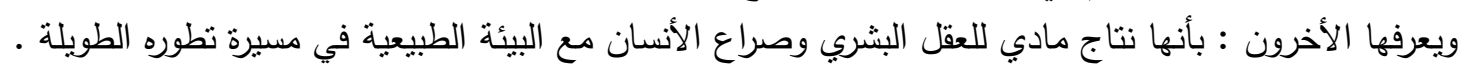
بنظر :

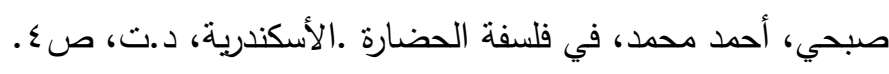

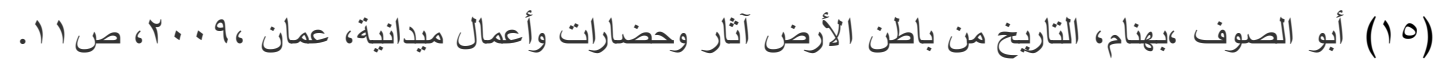

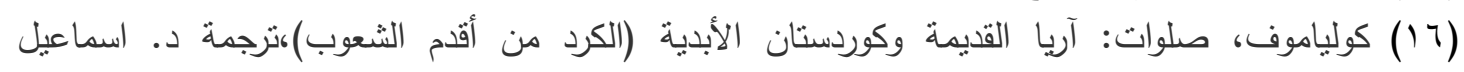

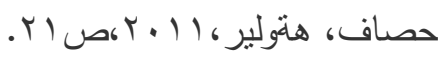

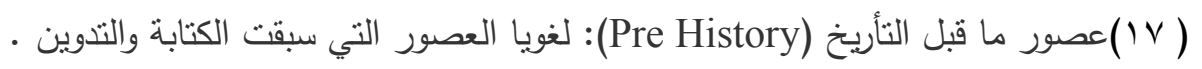

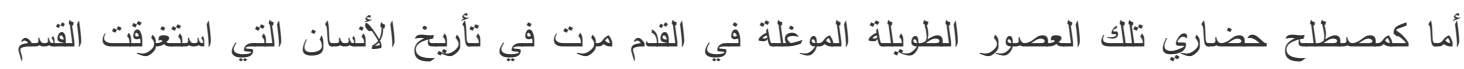

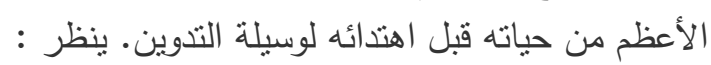

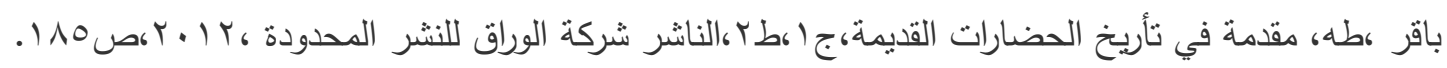

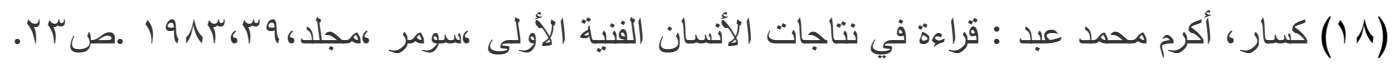

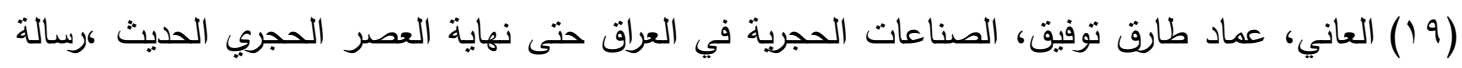

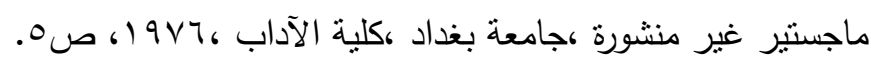

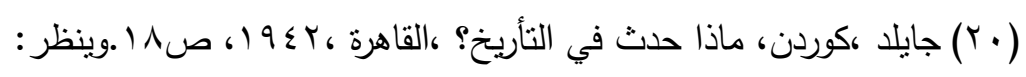

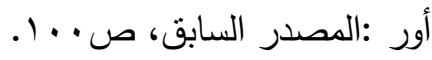

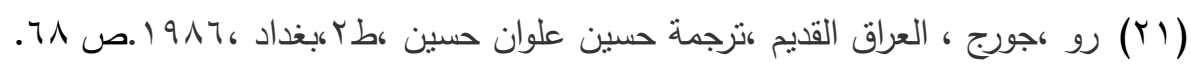

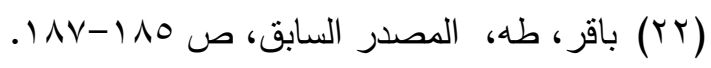

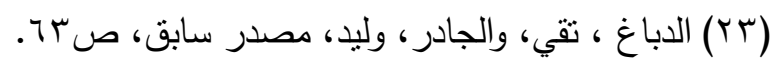

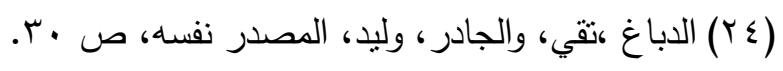

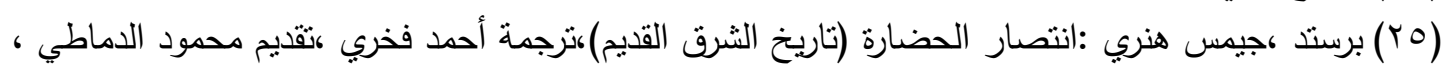

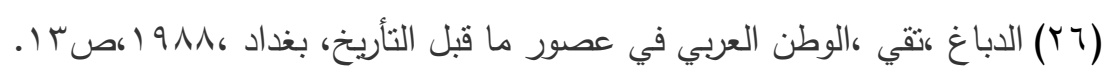

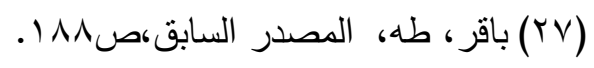


(28) Melville.H, Man and Hiswork, NewYork,1948.p.576.

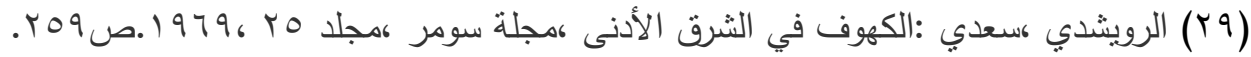

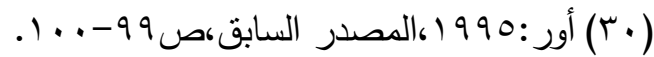

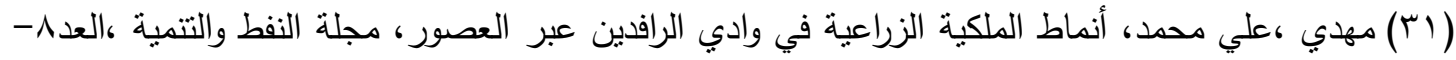

(rץ) سبتنيو ، موسكاتي، الحضارات السامية القديمة كترجمة السيد يعقوب بكر ومراجعة د. محمد القصاص،

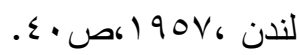

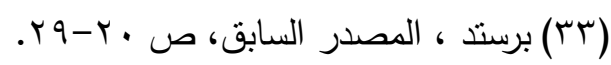

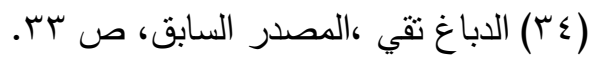

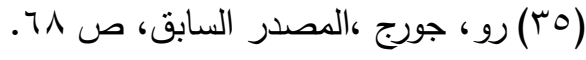

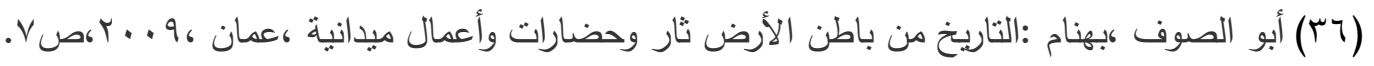

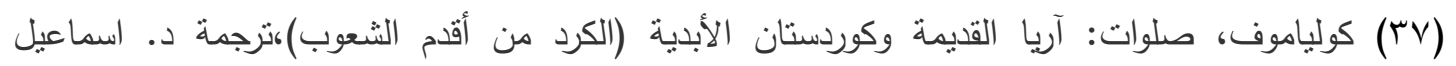

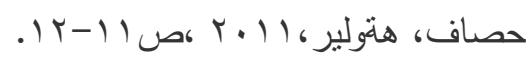

(38) BraidWood and How.1960.31.

(39) Braidwood,Robert.J.From Cave to Village ,An Article from Sceintific American,Vol.187.No4.1952.P.63

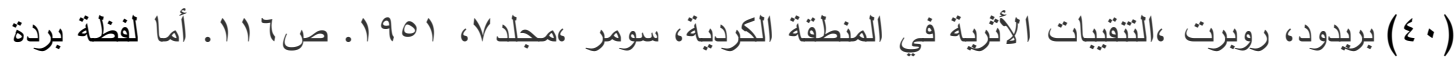

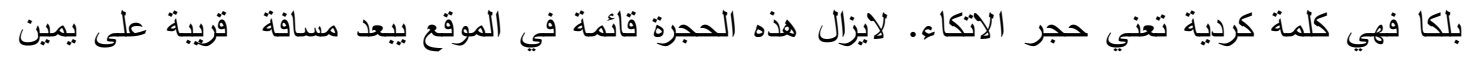

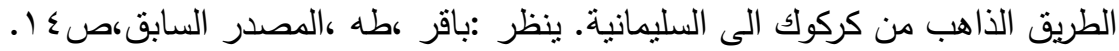

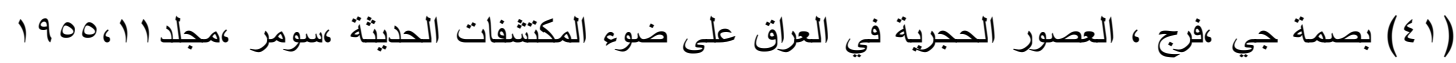

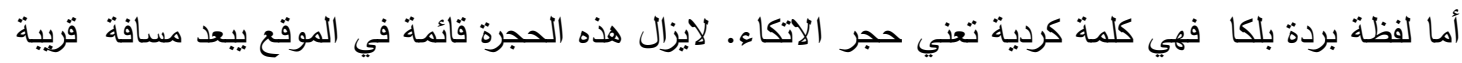

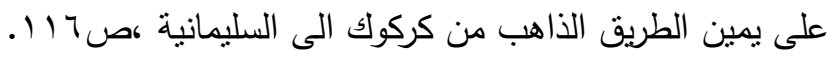

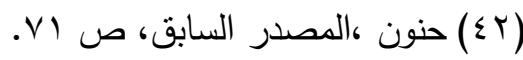

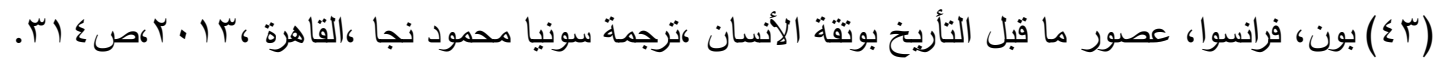

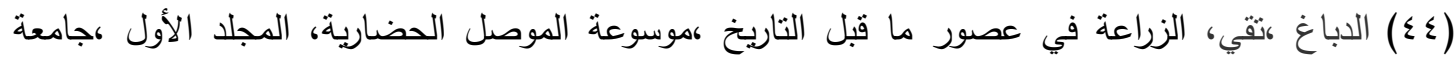

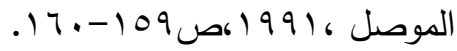

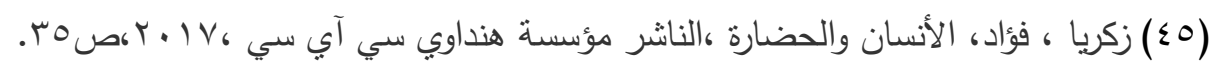

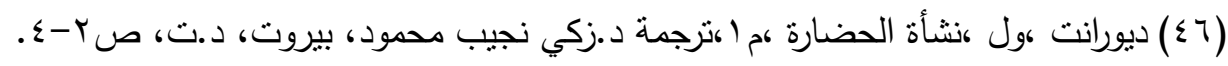

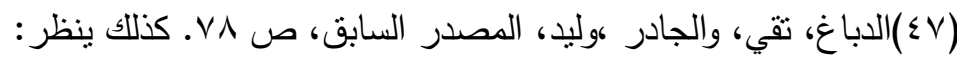

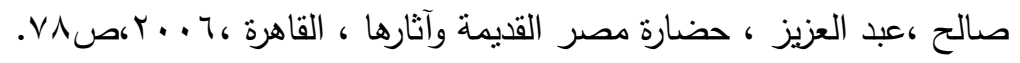

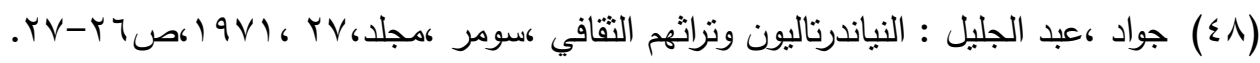

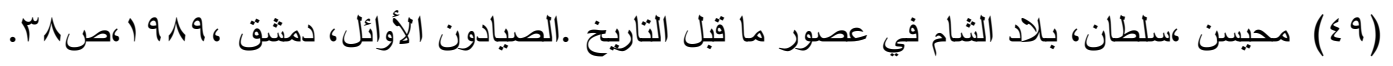

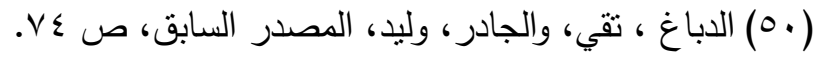

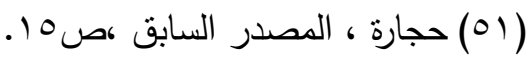

(52)Braidwood.and.Hoow.1960.2.

(53) Hawkes.J.1963.167 .

(54) Solecki R, Shanader Cave A Paleolithic Site In Northern Iraq and Its Relationship to the Stone Age Sequence of Iraq. Sumer.11.1955.P.15-33.

(55 Solecki.R. Apalaeolihic Site in the Zagros Mountain of Northern Iraq. Sumer.8,No2.1952. P.137. 
(56)Solecki.R.Shanidar Cave ,in Scientific American ,Vol.197 ,No.5 , 1957.P.6.

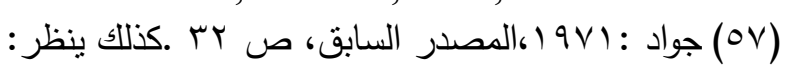

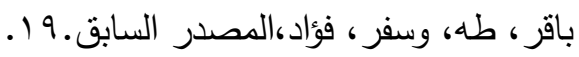

(58) Solecki,R. Three adult Neanderthal skeletons from Shanidar Cave Northern Iraq . Sumer.Vol.17,1961.pp.80-85.

(61)Ralph,Solecki,1958.102-104.

$$
\begin{aligned}
& \text { (709)أور، فرنسيس، المصدر السابق، ص9911) }
\end{aligned}
$$

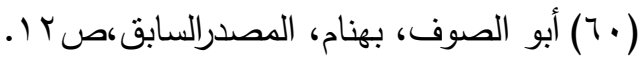

(YT)الهاثني ،تغريد جعفر وعكلا ،حسن حسين، الأنسان تجليات الأزمنة ،تأريخ وحضارة بلاد الرافدين

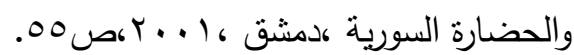

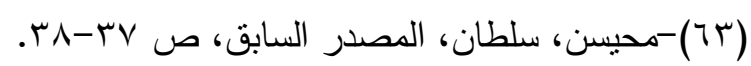

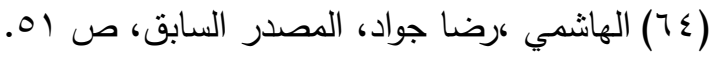

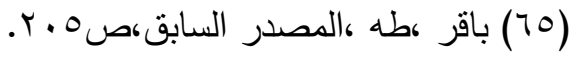

(67) Garrod. D.1930.13

(68) BraidWood and How.1960. 29-30 .

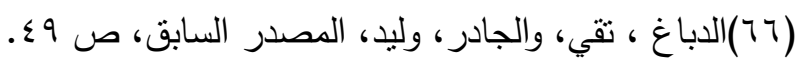

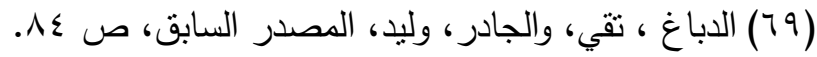

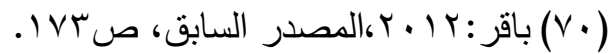

(71) Solecki.R.1957.61.

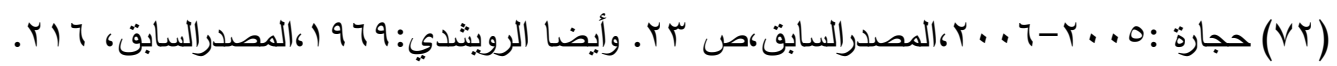

(73) BraidWood and How.1960 .57-58.

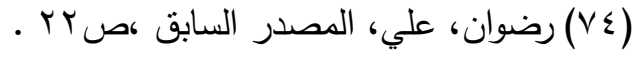

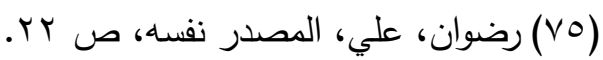

$$
\begin{aligned}
& \text { (VT) }
\end{aligned}
$$

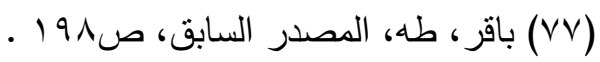

$$
\begin{aligned}
& \text { (VA) }
\end{aligned}
$$

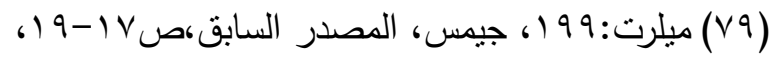

(80) Garrod,1930.12-14 .

$$
\text { (1) ميلرت، جيمس، المصدر السابق،صل ا-9 (1). }
$$

(82) .(Braidwood and How.1960;.28,29

(83) Braidwood, Robert.J. ;1952.p5.

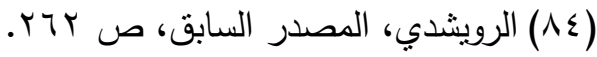

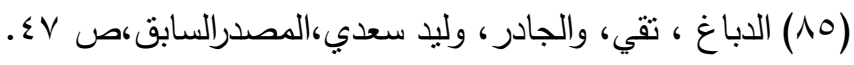

(86) Braidwood Robert.J. ,1952; p5. 
المصادر العربية والأجنبية

1- أبو الصوف ،بهنام .التاريخ من باطن الأرض. آنار وحضارات وأعمال ميدانية ،عمان ، $. r . .9$

ץ- أور ،فرنسيس ،حضارات العصر الحجري القديم ، ،تعريب د. سلطان محيسن ، الطبعة الثانية ،دمشق ، 1990.

ب- باقر طه وسفر فؤاد .المرشد الى مواطن الآثار والحضارة ،الرحلة الخامسة ،بغداد ، 1970 ـ

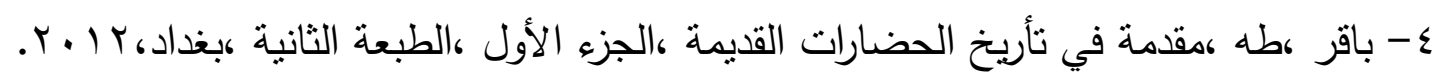

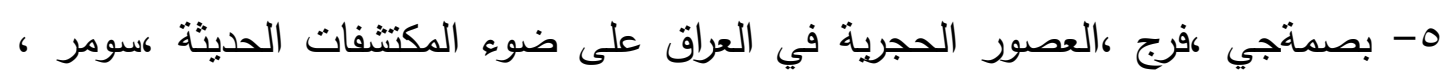
مجلد، 11900، 19.

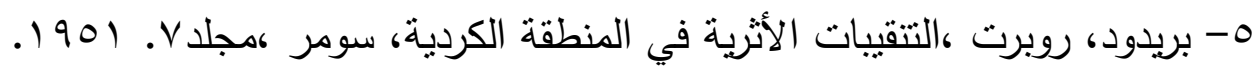

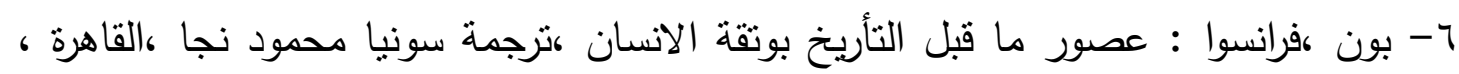
r. T

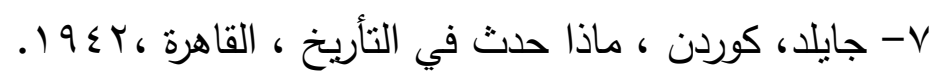

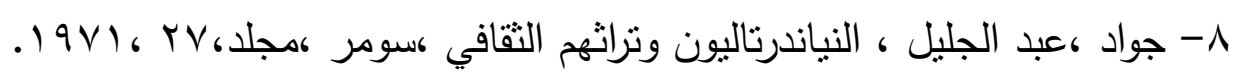

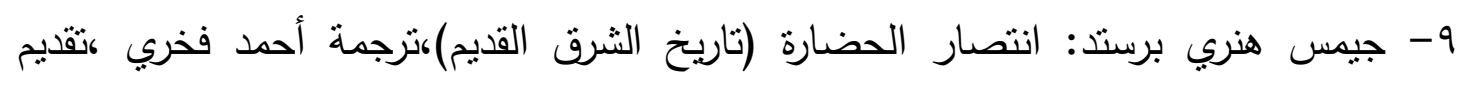

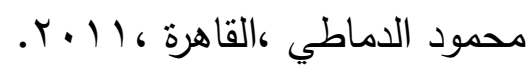
• 1- الجنابي، صلاح حميد، جغرافية الموصل .دراسة في العلاقات الإقليمية ،موسوعة الموصل ، الماطل

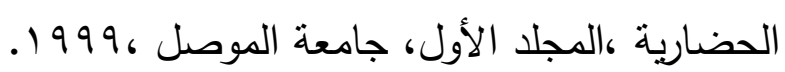

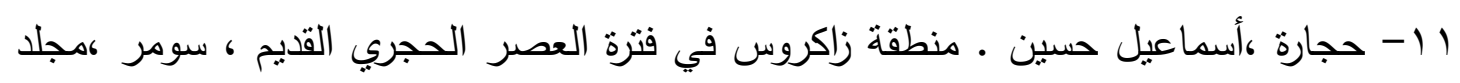

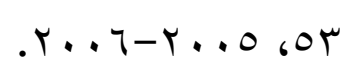

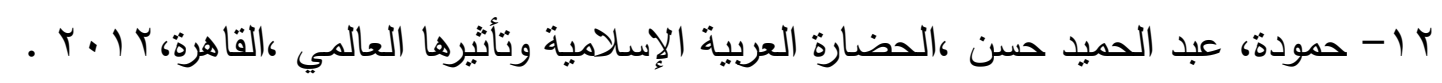

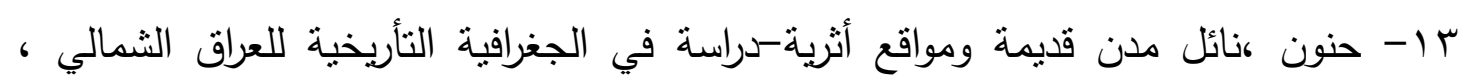
دمشق،

ـ ا - خصباك ،شاكر ، العراق الثمالي -دراسة لنواحيه الطبيعية والبشرية، بلو 19.

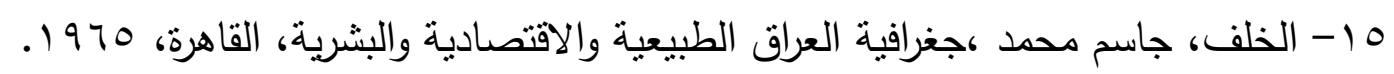
19 17 - الدباغ ،تقي ،علم الآثار ، بغداد ، 1911.

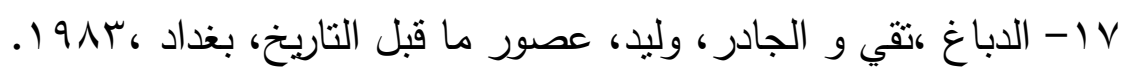

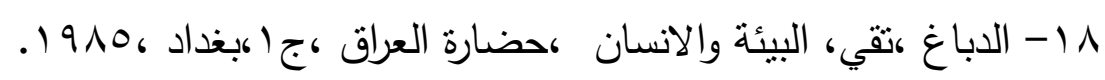

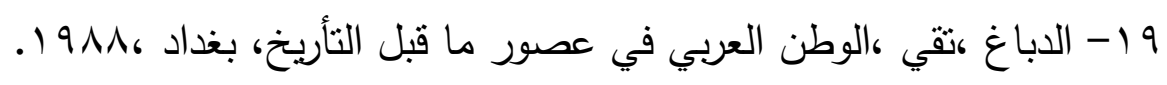


• r- الدباغ ،تقي ،الزراعة في عصور ما قبل التاريخ، موسوعة الموصل، المجلد الأول ،جامعة ،ولة الموصل ، 1991.

اب- ديورانت، ول، نشأة الحضارة ،ما، ترجمة: د. زكي نجيب محمود، بيروت -تونس بدون تاريخ.

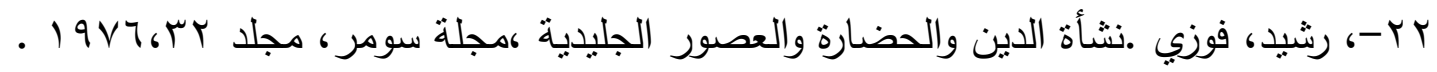

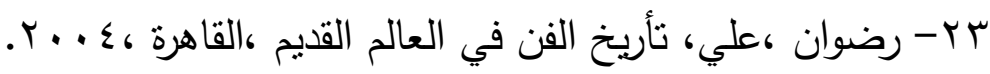

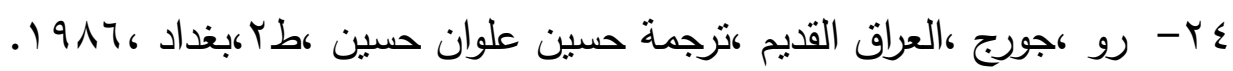

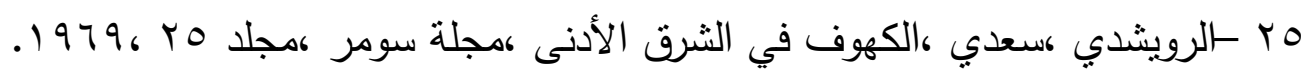

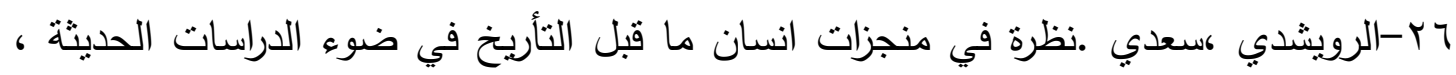
مجلة سومر ،مجلد بY، • 19V. V V - سبتينو، موسكاتي :الحضارات السامية القديمة كترجمة السيد يعقوب بكر ومراجعة د. محمد القصاص، لندن ، 190V.

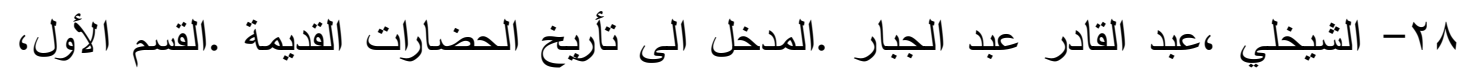
جامعة بغداد ، ـ 99 19.

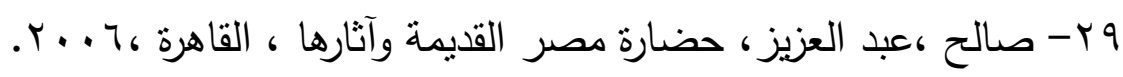
• ب-صبحي،أحمدممد،في فلسفة الحضارة ، الإسكندرية، (د.ت).

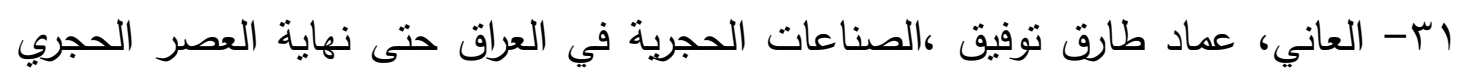

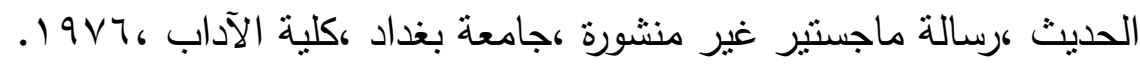

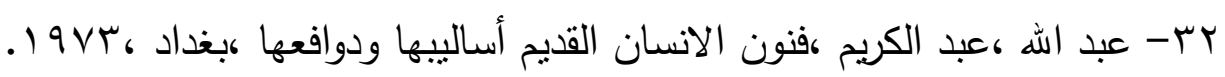

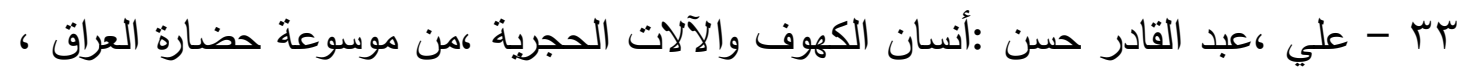

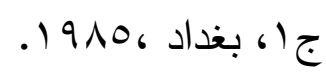

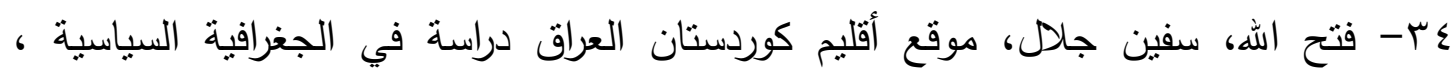

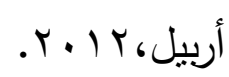
هب- كولياموف، صلوات ،آريا القديمة وكوردستان الأبدية (الكرد من أقدم الثعوب)،ترجمة د.

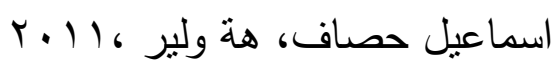

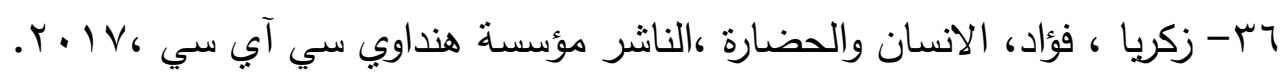

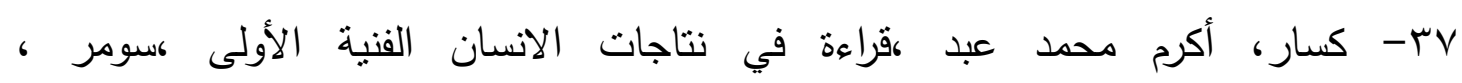

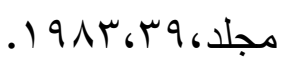


^ץ- لنتون، رالف ،شجرة الحضارة .قصة الانسان منذ فجر ما قبل التاريخ حتى بداية العصر

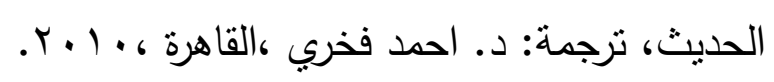

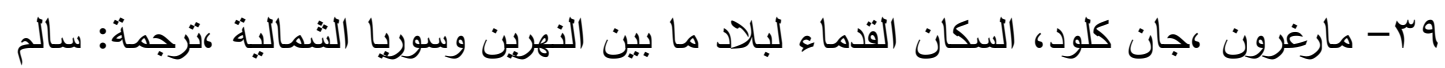

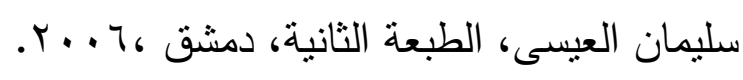

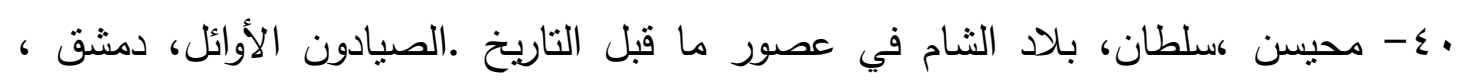
.1919

اء- ميلرت ،جيمس ، اقدم الحضارات في الثرق الأدنى ،ترجمة محمد طلب، دمشق ،

Y ؟ - مهدي ،علي محد ،أنماط الملكية الزراعية في وادي الرافدين عبر العصور، مجلة النفط

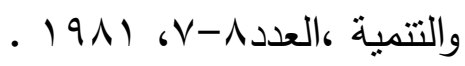

r؟- نيكينتين ،باسيل • الكرد .دراسة سوسيولوجية وتأريخية، نرجمة وتحقيق: الدكتور نوري

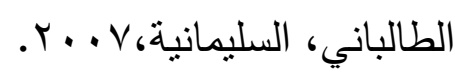

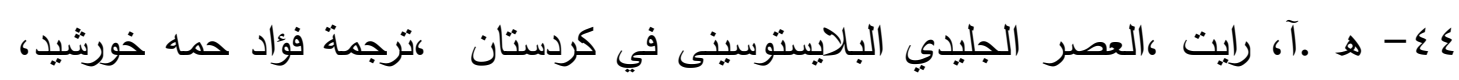

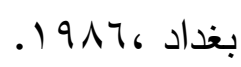

0ـ - الهاشمي ،تغريد جعفر وعكلا ،حسن حسين ،الانسان تجليات الأزمنة ،تأريخ وحضارة

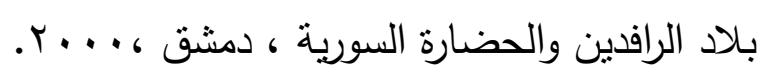

46- Braidwood, Robert.J, From Cave to Village ,An Article from Scientific American,Vol.187.No4.1952.

47-Braidwood, Robert.J., And How Bruce Prehistoric Investigations in Iraqi Kurdistan.Chicago.1960.

48-Garrod. D., Excavations in the Cave of Zarzi and Hazar Mered, American School of Prehistoric Research . Bulletin No.6. 1930.

49-Solecki. R, The 1956-1957 Season at Shanidar, Iraq a Preliminary Statement ,Sumer, 14,1958.

50- Solecki R., Shaneder Cave A Paleolithic Site In Northern Iraq and Its Relationship to the Stone Age Sequence of Iraq, Sumer,11,1955.

51-Solecki.R., Apalaeolihic Site in the Zagros Mountain of Northern Iraq , Sumer,8,No2.1952.

52-Solecki.R.,Shanidar Cave in Scientific American ,Vol.197 ,No.5 , 1957.

53-Solecki,R.,Three adult Neanderthal skletons from Shanidar Cave Northern Iraq, Sumer,Vol.17,1961.

54-Melville.H., Man and His work, NewYork,1948. 

Contents

\begin{tabular}{|c|c|c|}
\hline Page & Research Name & Subject \\
\hline 1 & Prof. Khalid Salim Ismael & Preface \\
\hline $3-82$ & Prof. Dr. Wathiq Al-Salihi & Palm Trees in the Arts of Mesopotamia \\
\hline $83-94$ & $\begin{array}{l}\text { Haneen Abdulghani Jasim } \\
\text { Prof. Khalid Salim Ismael }\end{array}$ & $\begin{array}{c}\text { Lights on the Royal Edicts from Old } \\
\text { Babylonian Period } \\
\text { Analytical Study }\end{array}$ \\
\hline $95-132$ & Prof. Dr. Amir Abdullah al-Jumaily & $\begin{array}{l}\text { Some of Caravan Route Cities and } \\
\text { Road Stations Throughout Ancient } \\
\text { And Islamic History in the Light of } \\
\text { Cuneiform Texts and Arabic Sources }\end{array}$ \\
\hline $133-160$ & $\begin{array}{l}\text { Asst.Pro.Dr.Fatimaa Abbas Salman } \\
\text { Pro.Dr. Saad Salman Fahed }\end{array}$ & $\begin{array}{l}\text { Tamarisk Tree in Light of Cuneiform } \\
\text { Writings A joint Submitted by } \\
\text { Research }\end{array}$ \\
\hline $161-186$ & $\begin{array}{l}\text { Assist-Prof.Dr. Noman Jumaah } \\
\text { Ibrahim }\end{array}$ & $\begin{array}{l}\text { The Achievements of Prehistoric } \\
\text { Human in Iraqi Kurdistan and } \\
\text { Manifestations of his Civilization } \\
\text { Until the End of the Upper Paleolithic }\end{array}$ \\
\hline $187-204$ & $\begin{array}{c}\text { Qassim Omar Allawi } \\
\text { Dr. Sufyan Yasen Ibrahim }\end{array}$ & Urban activities in Indian ports \\
\hline 205-221 & Dr. Hani Abdulgani Abdullah & $\begin{array}{c}\text { Appearances of Cleanliness in the } \\
\text { Hittite Society }\end{array}$ \\
\hline $223-250$ & Dr. Mustafa Mohsen Muhammad & $\begin{array}{c}\text { The (Gt) Stem in the Akkadian } \\
\text { Language a Semantic and } \\
\text { Morphological Study Comparing } \\
\text { Between Hebrew and Arabic } \\
\text { Languages }\end{array}$ \\
\hline 251-269 & $\begin{array}{c}\text { Asst.Lect. Abdulmakram } \\
\text { Mahmoud Mohammed Alezzi }\end{array}$ & $\begin{array}{l}\text { A Study of The Sumerian Term } \text { NIG }_{2^{-}} \\
\text {KAS }_{7 . .} \text { AK (Balanced Account)In The } \\
\text { Texts of The Third Millennium B.C }\end{array}$ \\
\hline $271-287$ & Lecturer. Hasan M. Hammoodi & $\begin{array}{c}\text { The Sickle Industry Developed In } \\
\text { Ancient Iraq During The Mesolithic To } \\
\text { The End Of Chalcolithic }\end{array}$ \\
\hline
\end{tabular}


12- The original research papers submitted to the magazine are not returned to their owners, whether published or not.

13- Tables and figures are numbered in a row according to their appearance in the research, provided with titles, submitted with separate papers, blueprints are submitted in black ink and images to be in high resolution.

14- The marginal numbers are written in parentheses and are presented in series at the end of the research.

15- The full source name is indicated in the margin, with the abbreviated source in parentheses at the end of the margin.

16- The researcher is responsible for correcting the linguistic and typographical errors in his research.

17- The magazine operates according to self-funding. Therefore, the researcher bears the publication fees of $(100,000)$ one hundred thousand Iraqi dinars.

18- Each researcher shall be provided with one copy of his research. As for the full copy of the journal, it is requested from the magazine's secretariat and a price is determined by the Editorial Board.

19- The papers should be sent to the journal e-mail:

uom.atharalrafedain@gmail.com 


\section{Publishing rules in Athar Al-Rafedain Journal (AARJ):}

1- The journal accepts scientific research that falls in specializations:

- Ancient Archaeology and Islamic Archaeology .

- Ancient languages with their dialects and comparative studies.

- Cuneiform Inscriptions and ancient lines.

- Historical and cultural studies

- Archaeological geology.

- Archaeological survey techniques.

- Anthropological studies.

- Conservation and restoration.

2- Research papers shall be submitted to the magazine in both Arabic and English.

3- The research shall be printed on (A4) paper, word-2010 system, with double spaces between lines, Simplified Arabic font for Arabic language, Times New Roman for English language, delivered on $\mathrm{CD}$, and in two paper based copies.

4- The title of the research should be printed in the middle of the page, followed by the name of the researcher, his academic degree, his full work address, and e-mail.

5- The research should contain an abstract in Arabic and English languages, it shouldn't exceed (100) words.

6- The abstract of the research in English contains the title of the research, the name of the researcher, his academic degree, his full workplace, and his e-mail.

7- The research must include keywords related to the title of the research and its content.

8- That the research was not previously published or was submitted to obtain a degree or is derived from the intellectual property of another researcher, and the researcher must undertake this in writing when submitting it for publication.

9- The researcher is obliged to follow the correct scientific foundations in his research.

10- The researcher is obligated to amend his research terms to suit the experts 'suggestions and the method of publishing in the journal.

11- The number of research pages does not exceed (25) pages, and in case of exceeding the required number, the researcher shall pay an additional amount for each additional page. 


\author{
Arabic Language Expert \\ Dr. Maan Yahya Mohammed \\ Dep. Of Arabic Language /College of Arts / University of Mosul
}

\author{
English Language Expert \\ Assist. Lect. Ammar Ahmed Mahmood \\ Dep. Of Translation Language / College of Arts / University of Mosul
}

Design Cover

Dr. Amer Al-Jumaili 


\title{
$\underline{\text { Editorial Board }}$
}

\author{
Prof. Khalid Salim Ismael \\ Editor-in-Chief
}

\section{Assist Prof. Hassanein Haydar Abdlwahed \\ Managing Editor}

\section{Members}

Prof. Elizabeth Stone

Prof. Adeileid Otto

Prof. Walther Sallaberger

Prof. Nicolo Marchetti

Prof. Hudeeb Hayawi Abdulkareem

Prof. Jawad Matar Almosawi

Prof. Rafah Jasim Hammadi

Prof. Abel Hashim Ali

Assist Prof. Yasamin Abdulkareem Mohammed Ali

Assist Prof. Vyan Muafak Rasheed

Assist Prof. Hani Abdulghani Abdullah 



\section{Journal}

\section{Athar Al-Rafedain}

Accredited Scientific Journal

It Search's in Archaeology of Iraq and Ancient Near East

Published by College of Archaeology - University of Mosul

E-Mail: uom.atharalrafedain@gmail.com

Vol.6 / No.2

Shwal. 1442 A.H. / June. 2021 A.D. 

$\frac{3}{3}$

University of Mosul College- of Archaeology

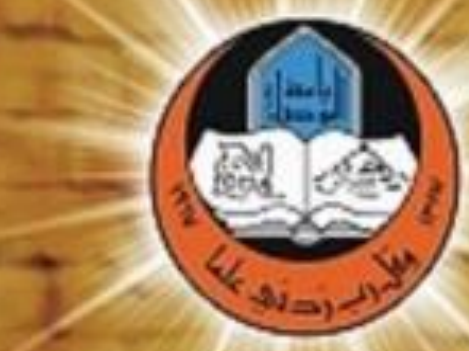

Ministry of Higher

Education and Soientific

Research

ISSN 2304-103X

|रि口प

Academx Socreithe soumals

2

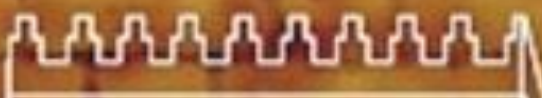

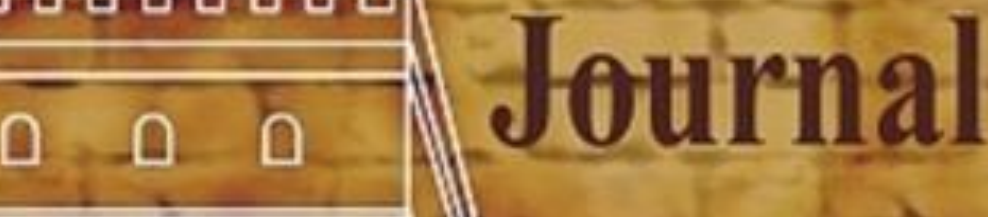

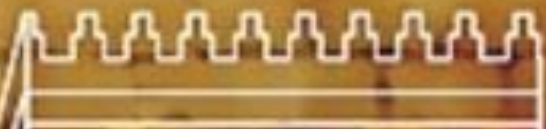

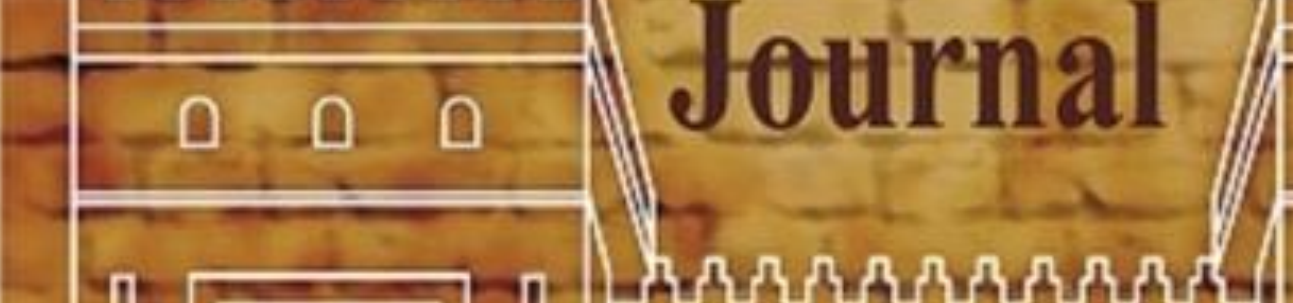

r

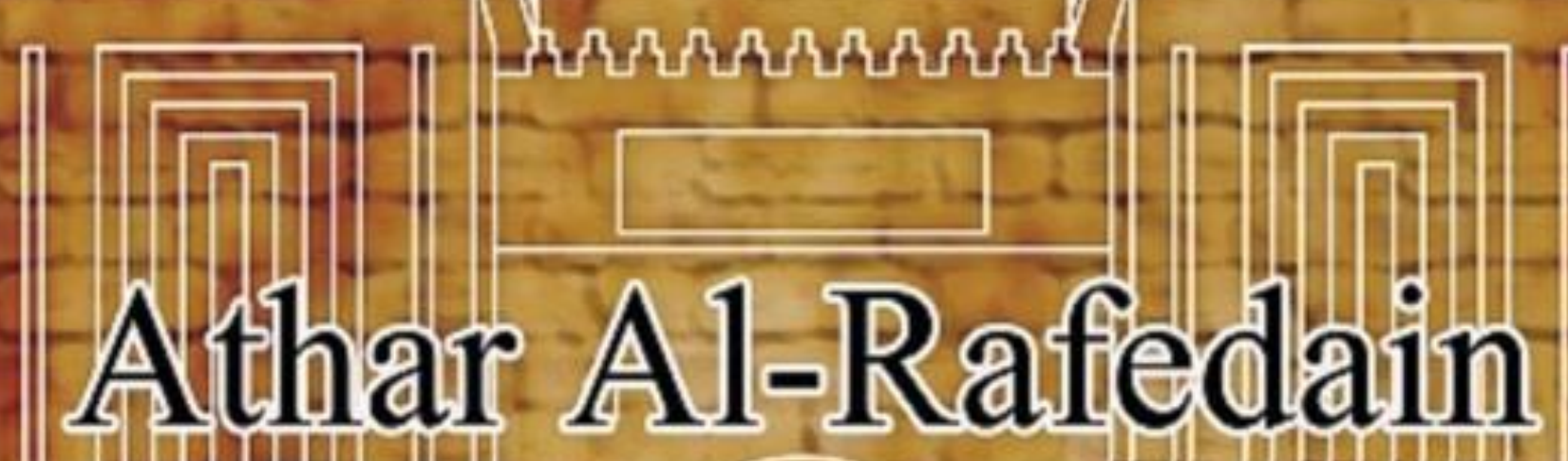

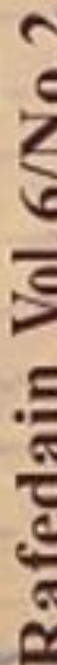

m.thin

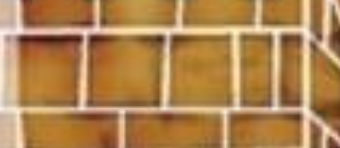

1 II

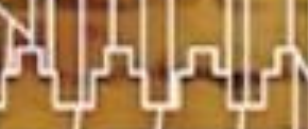
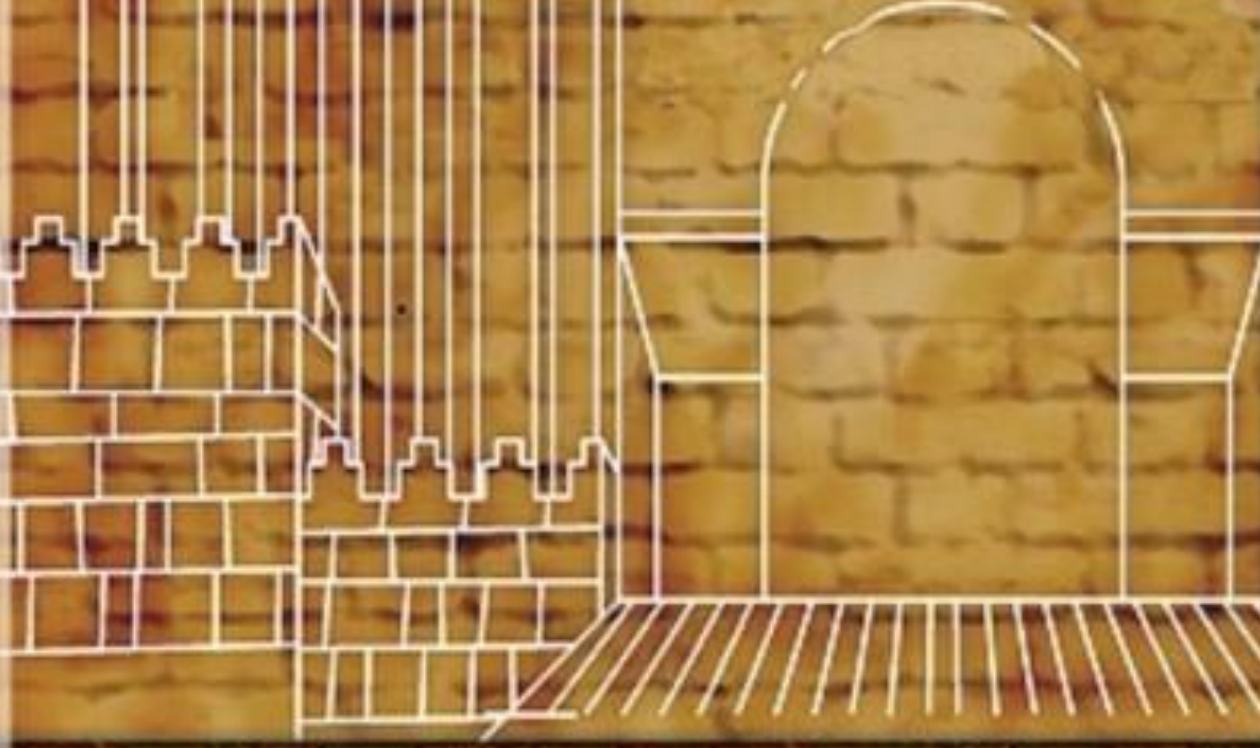

Q $-0 .-0$

$\frac{1}{2}$

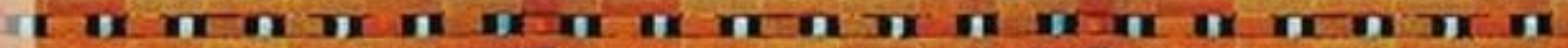

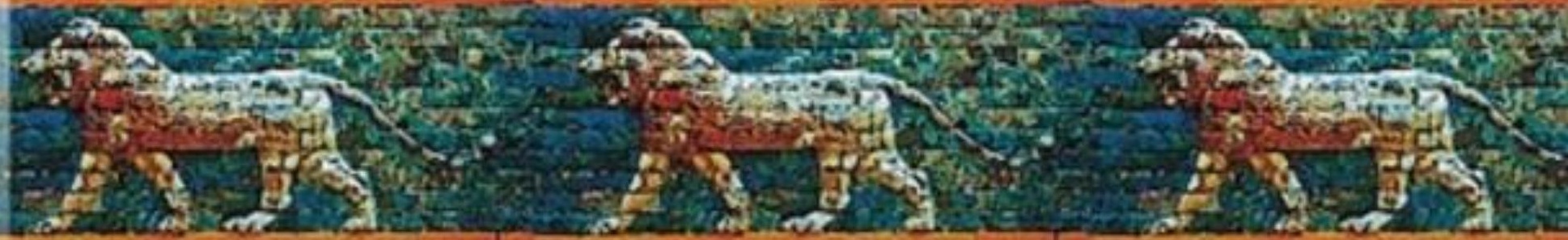

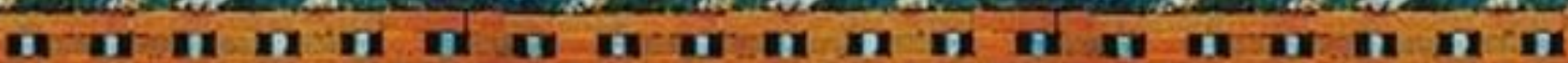

Accredited Scientific Journal It Search's in Archaeology of Iraq and Ancient Near East

Published College of Archaeology - University of Mosul / Vol.6/ No.2 / 1442 A.H. / 2021 A.D. 